\title{
Family involvement and firms' establishment mode choice in foreign markets
}

Article

Accepted Version

Boellis, A., Mariotti, S., Minichilli, A. and Piscitello, L. (2016) Family involvement and firms' establishment mode choice in foreign markets. Journal of International Business Studies, 47 (8). pp. 929-950. ISSN 1478-6990 doi:

https://doi.org/10.1057/jibs.2016.23 Available at https://centaur.reading.ac.uk/84155/

It is advisable to refer to the publisher's version if you intend to cite from the work. See Guidance on citing.

To link to this article DOI: http://dx.doi.org/10.1057/jibs.2016.23

Publisher: Palgrave Macmillan

All outputs in CentAUR are protected by Intellectual Property Rights law, including copyright law. Copyright and IPR is retained by the creators or other copyright holders. Terms and conditions for use of this material are defined in the End User Agreement.

www.reading.ac.uk/centaur 
Central Archive at the University of Reading

Reading's research outputs online 


\title{
FAMILY INVOLVEMENT AND FIRMS' ESTABLISHMENT MODE CHOICE IN FOREIGN MARKETS
}

\begin{abstract}
Extant literature on foreign entry increasingly recognizes firms' heterogeneity as a potential reason for inconsistency in results on the establishment mode choice, i.e. whether and under which conditions firms should choose to enter a new country through a greenfield investment or an acquisition. Our study contributes to this debate by identifying family ownership and family involvement in management as potential powerful sources of such heterogeneity. Integrating international business studies with both corporate finance literature on family firms and recent contributions from the Socio Emotional Wealth perspective on family ownership, we claim that, due to greater risk aversion and lower access to information, the family involvement either in the firm ownership and management leads to a higher propensity towards greenfield initiatives (vs. acquisitions). However, we also find that such a propensity decreases with international experience especially in family-owned firms given the greater ability of professionalized management to overcome family-related concerns on making acquisitions. Our analysis on 1,045 foreign initiatives undertaken by 311 Italian family and non-family firms between 2003 and 2013 confirms our expectations - indicating family ownership as a significant driver of international business choices.
\end{abstract}




\section{INTRODUCTION}

The literature on firms' entry into foreign markets has emphasized the importance of the establishment mode choice between a greenfield initiative and acquisition of an existing firm in the host market (e.g., Brouthers \& Brouthers, 2000; Padmanabhan \& Cho, 1999). Scholars applied several theoretical lenses, leading to a panoply of empirical findings and mixed conclusions about the role of several predictors (for a detailed review, see Slangen \& Hennart, 2007). Within this context, firm heterogeneity, and specifically that related to corporate governance, can help shed further light on the issue (Strange, Filatotchev, Buck \& Wright, 2009). In this paper, attention is devoted to the degree of family involvement in firm ownership and management. The significance of family business in modern economies is well documented in terms of both phenomenological and theoretical reasons. On the one hand, family firms (FFs) have been increasingly recognized as socially and economically dominant worldwide $^{1}$ (e.g., Gomez-Mejia, Makri, \& Kintana, 2010). On the other hand, the literature acknowledges important differences in the strategies of FFs vs. non-FFs (e.g., Miller, Le Breton-Miller \& Lester, 2010; Strike, Berrone, Sapp \& Congiu, 2015), including internationalization choices (Fernández \& Nieto, 2006).

We assert that FFs and non-FFs differ in their establishment mode choice abroad mainly relying on the following explanations. First, integrating contributions from the International Business (IB) framework, the Socio Emotional Wealth (SEW) approach (Berrone, Cruz \& Gomez-Mejia, 2012), and corporate finance literature on FFs (e.g., Anderson \& Reeb, 2003; Caprio, Croci \& Del Giudice, 2011), we argue that the family includes the firm in its utility function, thus developing an international growth approach that is averse to risk and dilution of control. Second, FFs hardly possess or have access to the relevant information needed to reduce the uncertainty associated with entering a foreign market, while non-FFs benefit from the greater contributions of external financial and institutional shareholders and professional managers (Tihanyi, Johnson, Hoskisson \& Hitt, 2003), who bring into the companies international experience gained in other firms, sectors, and markets. Third, distinguishing between family-managed firms (FMs), in which family members are simultaneously 
key owners and managers of the firm, and family-owned firms (FOs), in which the family dominates the shareholder base but managers are recruited externally (Chua, Chrisman, Steier \& Rau, 2012), we argue that the presence of the family within management is associated with a lesser endowment of relevant information and experience and constrains the exploration of valuable options for expanding abroad.

Building upon these pillars, we claim that the greater the family involvement in the firm's governance is, the more likely that the firm will prefer less risky (more cautious) entry modes in foreign countries, i.e., greenfield initiatives rather than acquisitions. However, information gathered directly on foreign markets helps reduce firms' risk perception. This effect is particularly relevant for FFs and especially FOs in which talented non-family managers have a superior ability to extract information and knowledge from the firm's experience in foreign markets (Levy, Beechler, Taylor \& Boyacigiller, 2007; Musteen, Datta \& Herrmann, 2009). Accordingly, because of their greater understanding (and tolerance) of risk, FOs will expand their choice set, and more acquisitions will occur.

We test empirically our hypotheses in the Italian context, which is an ideal test bed because it contains many flourishing large internationalized FFs (Miller, Le Breton-Miller, Minichilli, Corbetta \& Pittino, 2014). We consider Italian manufacturing firms with more than 50 million euros in revenue that undertook foreign entries in the period 2003-2013. As a result, we examine 1,045 foreign initiatives by 311 large Italian firms.

We believe that, cross-fertilizing IB literature with the debate on management practices and sociological characteristics of family businesses, our paper provides novel ideas to explain previous controversial findings about the relationship between firms' heterogeneity and the MNE's establishment mode choice in foreign markets.

The paper is organized as follows. In the next section, we illustrate the establishment mode trade-off and discuss the characteristics of FFs that make them differently equipped to face the uncertainty inherent in any foreign initiative. We then develop our conceptual analysis of the moderating role of international experience in the relationship between family involvement and establishment mode 
choice. The third section presents our data set and describes the variables and the statistical models.

The fourth section reports the econometric findings and some robustness checks, while the closing sections provide the discussion and some concluding thoughts on avenues of future research.

\section{CONCEPTUAL FRAMEWORK AND HYPOTHESES DEVELOPMENT}

\section{The establishment mode trade-off}

Under conditions of firms' liability of foreignness (Zaheer, 1995), the decision-making process regarding international growth is strongly affected by the market and event uncertainty characterizing the target countries, and benefits of internationalization may be difficult and costly to manage (Cumming, Knill \& Syvrud, 2016). Thus, the establishment mode choice can be seen as a trade-off between the wish to effectively enter the market and access local complementary assets, which would lead to the acquisition of a local company, and the need to reduce financial and business risks, which would instead recommend more cautious greenfield investments. Indeed, entering a foreign market through a greenfield venture allows a company to replicate the existing organizational structure and reduce the uncertainty related to interactions with a foreign company. Conversely, the acquisition of a local company constitutes the quicker way to access resources that are difficult to acquire via arm's length transactions, e.g. the foreign firm's knowledge base (Reiche, Harzing \& Pudelko, 2015). However, acquisitions bring their own set of risks, mainly related to adverse selection and moral hazard relevant to the seller-acquirer relationship (Reuer \& Ragozzino, 2014).

Several studies have investigated factors explaining how firms resolve the establishment mode tradeoff and there is a call for further research on the topic (Hennart \& Slangen, 2014). Among these factors, firms' heterogeneity has been held responsible for ambiguous results (Slangen \& Hennart, 2007). Here, we consider the heterogeneity related to the role of family involvement in firm ownership and management.

\section{Family firms' risk aversion and antidotes to uncertainty}

Recent advancements in family business studies revolve around the idea that what differentiates FFs from their non-FF peers is the orientation of family owners to pursuing economic and non-economic 
goals simultaneously. Reconciling predictions of agency and stewardship theories, the SEW approach offers a less normative view of managerial decision-making compared with classical economic models, in which economic and financial goals are balanced with family-centric social goals to preserve the stock of affect-related value that family owners have invested in the firm and to transfer the business to the next generation (Berrone et al., 2012). The deliberate purpose to combine economic and non-economic benefits of control and identification with the firm highlights a peculiar riskbearing attitude in FFs. Specifically, when facing decisions conferring economic gains to the firm but at the expense of SEW, compared with alternative actions that would preserve SEW, family principals will likely prefer the latter (Strike et al., 2015).

Put differently, because families often freeze a large proportion of their financial and emotional wealth in the firm, they act to preserve the business, thus becoming significantly risk averse and refraining from actions that can jeopardize their investment, undermining the family business's transgenerational continuity (Faccio, Marchica \& Mura, 2011). Furthermore, this risk aversion translates into families' resistance to every type of action that will potentially dilute their control of the firm (Caprio et al., 2011).

This attitude has relevant consequences for FFs' capital structure because families' behavior negatively affects the recourse to external equity and positively affects the use of internal funds (Koropp, Kellermanns, Grichnik, \& Stanley, 2014). Indeed, corporate finance literature has found that FFs follow a growth strategy that is inherently cautious and relies on a proper mix of self-financing and debt financing. Specifically, while FFs use similar levels of debt as non-FFs (Anderson \& Reeb, 2003), they have been found to be more prone to relying on internal rather than external funds (Caprio et al., 2011).

These financial decisions have relevant implications for the establishment mode choice in international operations. Being a priori averse to using external equity, when facing the opportunity to acquire a firm, FFs are often caught between two alternatives - debt or cash financing - both of which can have unpleasant side-effects. Indeed, debt-financed acquisitions can excessively increase financial leverage and bankruptcy probability (Furfine \& Rosen, 2011), while cash-financed ones imply a high 
probability of future unwelcome sales of new equity needed to offset the cash takeover (Marynova \& Renneboog, 2009). Consequently, FFs prefer greenfield investments that are more flexible and can be modeled gradually (Brouthers \& Dikova, 2010), thus being less risky and more easily self-financed.

FFs' higher propensity to make greenfield investments is reinforced when considering their lesser ability to deal with the inherent uncertainty of foreign markets. In fact, FFs are likely not sufficiently endowed with the relevant antidotes - i.e., information and experience - because, compared with nonFFs, they lack or only marginally present external financial and institutional investors and professional managers that bring previous and contextual international experience and practices into the firm. This additional information and knowledge can help non-FFs understand the long-term implications of their internationalization strategic choices (Musteen et al., 2009) and appear essential to managing more risky foreign operations, such as complex acquisitions, effectively (Strike et al., 2015).

Altogether, risk aversion, SEW, and lack of information characterize FFs and constrain the set of strategic alternatives that they perceive and evaluate (Arregle, Naldi, Nordqvist, \& Hitt, 2012). In this way, family involvement crucially influences the establishment mode trade-off in favor of greenfield investments, which are more consistent with the specific cognitive and emotional architecture of family principals ${ }^{2}$.

\section{Family-owned versus family-managed firms}

It is worth taking into account that family presence is not a dichotomous condition because family may be involved to different extents in firm ownership and management. Accordingly, we distinguish between FMs and FOs (Miller et al., 2014; Singla, Veliyath \& George, 2014).

First, it has been shown that the disclosure of firm activities is significantly lower in FMs than in FOs. Family managers leverage the higher degree of opacity to extract private benefits at the expense of minority shareholders (Anderson, Duru \& Reeb, 2009). It is reasonable to assume that FMs' opacity raises buy-side constraints over equity issuance - in addition to the sell-side reluctance to dilute control outlined above. Therefore, external equity is likely more expensive for FMs because minority investors discount the risk of being expropriated by family managers due to the high opacity of these 
firms, making the use of self-financing comparatively cheaper. As already posited, self-financing is more suitable to funding greenfield investments because of its steadiness and incrementalism.

Moreover, the endowment of relevant information and expertise on foreign markets can differ significantly between the two categories of FFs. In FOs, external professional managers are more likely equipped with international experience that compensates for the inexperience of family principals (Menon \& Pfeffer, 2003). Thus, hiring external managers helps overcome the risks associated with internationalization (Gomez-Mejia et al., 2010) and addresses a high degree of information asymmetry, thus promoting more acquisitions. In contrast, the overlap between family owners and managers that characterizes FMs will increase the non-economic concerns of decisionmakers. In particular, nepotistic appointments of family managers selected from a small pool of family heirs will decrease the likelihood that they possess competencies comparable with those of professionalized non-family managers. This entrenchment effect (Bertrand \& Schoar, 2006) exacerbates FMs' perception of risk in regard to establishment mode decisions.

Other features of FMs strengthen their orientation toward greenfields. First, core competencies in FMs are strictly embedded within the family boundaries, transmitted to the firm through the family's power and culture, and inclined to hew to path-dependent experience and traditions (Arregle et al., 2012). Because capitalizing on these idiosyncratic family-specific assets via acquisitions would require costly and risky integration with a local organization, FMs find it more suitable to enter a foreign country via a greenfield investment, which allows establishing the procedures and routines developed at home at a low marginal cost (Hennart \& Park, 1993). Second, when managers are selected among family members, the identity, rather than the mere alignment of interests between owners and managers, is ensured (Miller et al., 2014). Indeed, family managers will mutually reinforce the family owners' wish to avoid riskier operations and eliminate traditional agency costs, as well as empire-building attitudes often characterizing external professional managers. Hence, an increasing degree of family involvement in leadership positions will further increase FMs' reluctance to make SEW-threatening investments. 
Building upon the preceding arguments on non-FFs, FOs and FMs, we expect that the likelihood of expansion abroad through greenfield initiatives (rather than through the acquisition of pre-existing assets) increases with the degree of family involvement in the firm. Accordingly, our first hypothesis is as follows:

\author{
Hp1. The likelihood of entering a foreign market through a greenfield initiative (vs. \\ an acquisition) is higher for FFs than for non-FFs. Specifically, this is truer for \\ FMs than for FOs, other things being equal.
}

\title{
The moderating role of international experience
}

Previous studies have shown that international experience reinforces a company's antidotes to uncertainty in foreign markets (e.g., Dow \& Larimo, 2011). Specifically, a company's previous experience in a foreign market may reduce its liability of foreignness because the company learns how to deal with that country (Maitland \& Sammartino, 2015), i.e., to interface with local formal and informal institutions, the workforce, and the like, thus mitigating risk aversion and the related propensity to prefer greenfield investments (vs. acquisition). In our context, we argue that experience gained in the host country affects the establishment mode choices of non-FFs, FOs and FMs differently.

While non-FFs are already well endowed with information stemming from the presence of experienced external actors in the firm, FFs will benefit comparatively enormously from the gathering of specific information on the foreign market. Thus, reduction of the relevant uncertainty will reduce FFs' propensity toward greenfield investments (more than that observed in non-FFs). However, when distinguishing between FOs and FMs, we assert that the accumulation of specific international experience is likely to benefit the former even more. Indeed, thanks to their professionalization and previous complementary personal experience, FO managers are able to effectively absorb and transmit to family principals the information they lack and thus expand the firm's set of strategic alternatives ${ }^{3}$. 
In contrast, FMs might be less able to integrate host country experience into their future decisions due to less talented family managers. Hence, the marginal effect of additional information on FMs' establishment choice is likely weaker than in the case of FOs.

Based on these arguments, we expect that the moderating role of specific international experience on the establishment mode choice is greater for FFs than for non-FFs. However, FOs are more likely influenced than FMs, mainly because of the presence of external managers. Accordingly, we formulate the following hypothesis:

Hp2. Host country experience negatively moderates the relationship between family involvement and the likelihood of entering through a greenfield initiative (vs. an acquisition). Specifically, this is truer for FOs than FMs, other things being equal.

\section{METHODOLOGY}

\section{Data set and summary statistics}

To build the dataset, we use two secondary sources: the Reprint database, developed at Politecnico di Milano, which provides a census on foreign entries undertaken by Italian firms worldwide (Mariotti, Mutinelli \& Sansoucy, 2015), and the Observatory AUB of Italian Family Businesses (Miller et al., 2014), developed at Bocconi University, which lists governance and accounting data on Italian FFs.

We focus on Italian firms operating at home in manufacturing industries ${ }^{4}$ with more than 50 million euros in revenue (according to the European Union classification of large firms). The adoption of this threshold excludes smaller firms whose internationalization strategies might be a priori constrained by the lack of financial and human resources, thus distorting our analysis of the establishment mode choice.

Firms are classified into three categories: non-FF, FO and FM. In accordance with Miller, Minichilli, \& Corbetta (2013), we distinguish between non-FFs and FFs, the latter being those firms that are 
controlled by one or two families with a $50 \%$ (if unlisted) or $25 \%$ (if listed) stake, or by an entity to which the above conditions apply ${ }^{5}$. Furthermore, FFs may or may not be managed by the owning family. It is common in FF literature to assume that a firm is family managed if the leader of the firm is a member of the owning family (Banalieva \& Eddleston, 2011; Miller et al., 2013). We define the leader as the CEO, the executive chairman of the board or the managing director without a formal board of directors. If a family member holds one of these positions, we consider the firm a FM. Otherwise, we define the firm as a FO.

Regarding foreign entries, we consider all the operations abroad, excluding retail (i.e., stores and showrooms) because investments in retail activities are usually highly fragmented and complete information about them is difficult to collect. Specifically, we include all the equity-based operations, ranging from fully-owned subsidiaries to joint ventures and minority partnerships. In this way, we adopt a two-way classification of the entries by distinguishing greenfield investment from acquisition and controlling (majority) from non-controlling (minority) ownership, the latter being defined as the possession of a stake equal to or less than $50 \%$ in the foreign company.

By using the above criteria and after crossing the information between the two data sets to eliminate those records for which complete information on either the parent company or foreign entry is not available, we obtain a final dataset of 1,045 entries undertaken by 311 Italian firms in 63 foreign countries during the period 2003-2013.

Table 1 presents some statistics of the sample. Specifically, the lion's share (corresponding to 68\%) of the total number of firms is constituted by FMs, which are responsible for $62 \%$ of the recorded foreign entries, FOs are $22 \%$ of the sample and account for $26 \%$ of the foreign initiatives, and the remaining is due to non-FFs ${ }^{6}$. On average, the sample firms have 768 employees and, notably, both FOs and FMs are larger than non-FFs, thus confirming the relevance of FFs in the Italian economy.

As to the distribution between greenfields and acquisitions, it emerges that FMs prefer to establish ventures from scratch in 420 cases of 649 foreign entries (64.72\%). This value is slightly lower for FOs (64.34\%), while it significantly differs for non-FFs (31.45\%), thus providing some preliminary 
evidence in favor of the first hypothesis. Regardless of the establishment mode chosen, it emerges that firms largely opt for majority investments rather than minority ones. When the investor decides to undertake a greenfield investment, it chooses to hold the majority of the equity stake in 562 cases of $634(88.64 \%)$. There is no significant difference between FOs and FMs in this choice $(89.14 \%$ vs. 89.76\%), while non-FFs have a lower preference for maintaining control over the subsidiary (which occurs in $74.36 \%$ of the greenfield investments). Firms' preference for control also holds for acquisitions. Indeed, firms in our sample on average opt for controlling acquisitions in 364 of 411 cases (88.56\%). FOs show a higher preference for majority acquisitions (95.88\%), while FMs report $87.77 \%$ and non-FFs $82.35 \%$. However, no significant difference emerges between the preferences for majority or minority investments conditional on the establishment mode chosen for every category.

\section{[insert Table 1 about here]}

Table 1 also shows that, on average, non-FFs undertake more foreign entries than their family counterparts (both FOs and FMs). Indeed, while the former undertake on average 4.28 foreign entries, the latter account for 3.94 and 3.05, respectively. Again, the main explanation resides with acquisitions because non-FFs show almost double the number of acquisitions per firm that FFs do. However, it is worth noting that the magnitude of this difference is contingent on the foreign context. Indeed, from the Observatory AUB of Italian Family Businesses, it emerges that non-FFs' average acquisitions per firm on the domestic market are only 1.15 times the average of FFs.

This descriptive evidence already provides some insights on the role of family control in firms' international growth. In particular, the exacerbation of the difference between the acquisition propensity of FFs and non-FFs in the international context is consistent with our interpretation grounded in the fundamental relationship between liability of foreignness, information costs and riskaversion on the part of FFs. Furthermore, the declining number of foreign operations observed from non-FFs to FOs and FMs helps support our argument of a constrained choice set.

Likewise, to provide some preliminary evidence for our second hypothesis, we report the share of foreign entries in a given country that are preceded by at least one other investment in the same 
country in the previous years (starting from 2000) by the same firm. Table 1 shows that non-FFs have already entered the target foreign country in $45.16 \%$ of the cases. The share is definitely weaker for FOs and FMs, which account for $22.79 \%$ and $24.65 \%$, respectively. When we condition this probability to the establishment mode, we see that non-FFs have comparable experience in the host country both when they opt for greenfield and when they select acquisition (43.59\% vs. $45.88 \%)$. The result changes dramatically for FOs. Indeed, when FOs opt for acquisitions, they possess more host country experience $(43.30 \%)$ than when they establish a venture from scratch (11.43\%). This finding suggests that as FOs acquire experience in the host country, they are likely to prefer acquisitions and behave similarly to non-FFs. The impact of international experience on the establishment mode is also evident in FMs, although it is weaker than among FOs. Indeed, when FMs opt for greenfields, they are less likely to possess host country experience (17.86\%), while this share is higher (37.12\%) when they decide to acquire a foreign subsidiary.

Finally, we investigate whether there is any particular trend in the establishment mode conditional on the country entered. In Table 2, we present the foreign entry distribution by country and the percentage of greenfield initiatives. It emerges that the share of greenfield investments is higher in developing and newly industrialized countries (e.g., China, India, and Russia), while acquisitions are more frequent in highly developed ones (e.g., the United States, the United Kingdom, and Germany). An explanation is that acquisitions are affordable in countries where there are plenty of established firms and a developed market for corporate control. We consider this aspect in the following regression analyses?

\section{[insert Table 2 about here]}

\section{Dependent variable and econometric model}

To model companies' establishment mode choice, we consider a dummy variable (Establishment mode choice) that equals 1 when the focal entry is a greenfield initiative and 0 when it is an acquisition.

Given the dichotomous nature of the dependent variable, we employ probit models to study the effect of the selected regressors on the likelihood of choosing a greenfield rather than an acquisition. We use 
a two-way fixed-effects model for the regression analyses. The first set of fixed effects refers to twodigit NACE code industry dummies in the sample (from 10 to 33), while the second accounts for each year of the foreign entry in the sample (from 2003 to 2013). Because many firms are responsible for several foreign entries in the period under investigation, it seems reasonable to assume that there exists a correlation among choices undertaken by the same parent company. Thus, we adopt firm-level clustered standard errors.

\section{Explanatory variables}

To account for the involvement of the family in the parent company, we build three dummy variables. Specifically, Non-family firm is a dummy variable taking the value of 1 if the parent firm is a non-FF and 0 otherwise. It constitutes the base level of our analyses. Likewise, Family owned and Family managed take the value of 1 if the parent firm is a FO or a FM, respectively, and 0 otherwise. However, both family ownership and family management may be an endogenous choice to the establishment mode chosen. Family ownership may be endogenous in the sense that families may decide to dilute their stake in the firm by issuing new equity - until the point in which they do not control anymore the firm and it ceases to be classified as a family firm - when they want to pursue an acquisition-based strategy. However, such cases are very limited in our sample. Overall, 14 firms (4.50\% of the sample) switch from being family firms (either owned or managed) to non-family firms and they are responsible for 71 foreign entries ( $6.79 \%$ of the total). The t-test on the differences in greenfield ratios (over total entries) before and after the switch does not reject the null hypothesis that the two ratios are equal. Even though we do not instrument the model, thus ruling out any potential endogeneity, we can claim that there is no evident change in the establishment mode choices following the ownership shift. We replicate the same analysis with regard to the choice of changing management to pursue a given international strategy. In other words, if a FF decides to expand aggressively through acquisitions, then it might be more prone to appoint a non-family leader beforehand to take advantage of her/his managerial skills and experience. Only nine (2.89\% of the sample) FFs change their leader during the reference period, and they are responsible for 28 foreign entries (2.68\% of the total). Among them, seven FFs switch from a family leader to a non-family one; the remaining two switch 
from a non-family leader to a family one. Examining the greenfield ratios (over total foreign entries) over the total foreign entries before and after the change, we find no significant difference ${ }^{8}$.

The company's host country experience is measured by a count variable (Host country experience) that reflects the number of initiatives that a MNE has already undertaken in a given country at the time of the entry, starting from 2000. Doing so allows us to compute MNEs' host country experience also for the entries in the first years of the period considered (e.g., the year 2003).

\section{Control variables}

To control for other factors that have traditionally been shown to influence MNEs' establishment mode choice, we add deal-, firm- and country-specific variables. When variables are time varying, they refer to the year preceding the foreign entry to ensure causality. A detailed description of the variables' operationalization and source is reported in Appendix 1.

\section{Deal-level controls}

The same firm can undertake greenfield or acquisition for different entries in the same or other host countries, depending on the motivation for the investment and the resulting need to access complementary assets (e.g., investments can refer to a new distribution location, a core manufacturing activity, a diversification of the firm's product portfolio, a backward/forward vertical expansion, and so on). Accordingly, we create four mutually exclusive dummy variables: Expansion in services, Horizontal expansion, Vertical expansion, and Diversification.

The probability of undertaking a greenfield investment decreases when the need for complementary assets in the host country increases. Complementary assets - such as tacit knowledge, specialized resources, and country-specific assets - may not be accessed via arm's length transactions. We expect that a firm's propensity to acquire rather than build is less pronounced in the case of expansion in services, the bulk of which are sales, distribution, and marketing. With the exception of some downstream activities, such as customization and adaptation processes to address the specific needs of local customers, these services do not significantly require local complementary assets. Indeed, the acquisition propensity increases when a firm must expand its production along horizontal or vertical 
linkages or must operate in new industries because it cannot exclusively rely on internal competencies and resources.

\section{Firm-level controls}

Parent size. Parent size may have mixed effects on the establishment mode choice. On the one hand, larger firms may possess more idiosyncratic tangible and intangible resources, and greenfield investments facilitate these resources' exploitation abroad. On the other hand, larger firms are likely to possess more financial resources, allowing them to make heavy investments, such as acquisitions. Parent age. Older firms are more likely experienced in their business. We control for this generic experience, distinguishing it from specific international experience. Parent diversification. Firms domestically active in several industries may have developed skills and capabilities in sharing and integrating diversified complementary assets. Therefore, they may also be more inclined to acquire assets in foreign countries (Brouthers \& Brouthers, 2000; Dow \& Larimo, 2011). Labor intensity. Labor-intensive firms may prefer greenfield entries to acquisitions because post-acquisition integration costs can be very high due to over-employment problems (Siegel \& Simons, 2010). Listed. Because we select a different threshold to detect family control in listed and unlisted firms (25\% vs. $50 \%)$, we control for potential differences between them. Leverage. Firms with a high level of debt may be hindered in collecting the resources needed to expand abroad. Although this is true for every investment, acquisitions usually require a huge amount of money in a limited time span. For this reason, we expect that firms with a heavy financial structure will find it more viable to enter through a gradual greenfield investment. Cash flow on assets. As a corollary to the previous rationale, firms that generate more operating cash flow must rely less on debt and find it easier to acquire foreign firms.

\section{Country-level controls}

Psychic distance. The greater the psychic distance is between home and host countries, the higher the perceived uncertainty is, thus pushing the parent company to opt for greenfield investments because they allow choosing from the outset the workforce, business routines, and other components (Hennart \& Park, 1993). Geographic distance. The physical distance between home and host countries 
contributes to increase the firms' perceived uncertainty as well as the agency and transaction costs relevant to acquisitions (Malhotra \& Gaur, 2013). GDP growth. In fast-growing markets, there is more room to absorb additional supply of goods (Brouthers \& Brouthers, 2000). By definition, greenfield investments add extra capacity in the host market, while acquisitions do not. GDP per capita. Acquisitions may not be an option to enter developing countries, where a strong and diversified industrial structure does not yet exist. We control for this aspect by inserting the GDP per capita as a proxy for the host country development. Market capitalization. Acquisitions are more likely where a market for corporate control exists and is liquid. We then calculate the market capitalization over the GDP as a proxy for the market for corporate control development. Time to start a new business is a proxy for the difficulty of establishing a new firm in the host country. Other things being equal, the more that is required to start a new business, the higher the costs associated with a greenfield investment are. Economic freedom. Countries with low levels of economic freedom raise barriers to acquisitions (e.g., Padmanabhan \& Cho, 1999).

\section{RESULTS}

Table 3 shows the descriptive statistics of the dataset. In addition to the mean and standard deviation of the variables, we also report the pairwise correlations. Examining the correlations, none seems to suggest multicollinearity issues. To remove any doubt, we compute the variance inflation factor (VIF). To reject the hypotheses that variables' correlations give rise to multicollinearity, each of the VIFs should be lower than 10, while the mean VIF should be lower than 6 (Hair, Black, Babin \& Anderson, 2010). In the sample, neither threshold is violated, with the highest single VIF 5.74 (psychic distance) and mean VIF 2.19.

[insert Table 3 about here]

[insert Table 4 about here]

Table 4 presents the results of the regression analyses ${ }^{9}$. Model (1) includes only the control variables ${ }^{10}$. We first focus on the deal-level controls. We adopt Expansion in services as the base level. As 
expected, the three motivations considered - horizontal and vertical expansion and diversification are negatively correlated with the propensity toward greenfield investments because these motivations imply proportionally more access to country-specific complementary assets than in the case of expansion in services. Acquisitions of local firms can be a more efficient way to access these assets. Examining the coefficients, not surprisingly, Diversification shows the highest difference from the base level, being associated with exploration strategies searching for new market and technology opportunities in sectors in which the firm is not active domestically $($ coefficient $=-1.18 ; p$-value $<$ 0.05). Vertical expansion has the lowest difference (coefficient $=-0.62$; $\mathrm{p}$-value $<0.05$ ), while Horizontal expansion fits in the middle (coefficient $=-0.84 ; \mathrm{p}$-value $<0.001)$.

Moving to the firm-level controls, Parent size positively influences the probability of choosing a greenfield investment, while the coefficients of variables approximating financial constraints do not come out significantly different from zero ${ }^{11}$. Finally, listed firms are keener to acquire. Possible explanations may reside in the fact that these firms are more used to operating in the equity markets and perhaps can benefit from knowledge externalities, being part of well-informed financial networks.

Concerning country-level controls, more developed countries favor the acquisition of local firms, as predicted. Analogously, although the related variable (Market capitalization) is not significant, countries with advanced markets for corporate control favor acquisitions. It is worth noting that psychic distance does not turn out to be significant, in line with previous studies (e.g., Brouthers \& Brouthers, 2000; Padmanabhan \& Cho, 1999) and some criticism about the constructs of this variable (Shenkar, 2001) $)^{12}$.

In model (2), we test hypothesis 1 . The model shows that both FMs and FOs are significantly more likely to make greenfield investments than non-FFs (that is the base level). The average marginal effects - reported in model (2) of Table 5 - suggest that FMs and FOs are 27\% and 28\% more likely to establish a greenfield than non-FFs, respectively (p-values $<0.001$ ). However, there is no difference in greenfield propensity between FOs' and FMs' coefficients $(\mathrm{p}$-value $=0.94)$, showing that family involvement in management, and the consequent idiosyncrasy of family-specific assets, has a minor impact, not sufficient to justify a further increase in the propensity to choose greenfield investments, 
with results indeed very high for both FOs and FMs compared with non-FFs ${ }^{13}$. Therefore, hypothesis 1 is partially supported.

\section{[insert Table 5 about here]}

Model (3) in Table 4 includes host country experience. Consistent with previous results (e.g., Dow \& Larimo, 2011), the coefficient is negative and significant and the average marginal effects show that, when Host country experience increases by one, the likelihood of choosing a greenfield decreases by $2.44 \%$ (p-value < 0.05), as is apparent in model (3) in Table 5.

To test hypothesis 2, model (4) in Table 4 analyzes the interaction effects between family involvement and the parent's host country experience. Because the interpretation of the estimated results for the interaction terms is not as straightforward as for linear models (Ai \& Norton, 2003), we rely upon graphical analysis as a supplementary method to coefficient testing (Hoetker, 2007). Additionally, because the findings could be invalidated if the groups have different unobserved heterogeneity, we also perform the Allison test (Allison, 1999) to avoid any potential interpretation error. The null hypothesis of the same unobserved variance is not rejected with a p-value of 0.90 . Thus, we can compare the moderation terms.

\section{[insert Figure 1 about here]}

From model (4) in Table 4, it emerges that host country experience negatively moderates FOs' propensity to enter a foreign country through greenfield (coef. -0.24 ; p-value $<0.05$ ); conversely, it does not show any significant effect on FMs. To clarify the point, Figure 1 depicts the average marginal effects of choosing a greenfield investment (y-axis) by FOs and FMs - relative to non-FFs at various levels of host country experience (x-axis). We compute the marginal probability - relative to non-FFs - to establish a greenfield initiative between the minimum ( 0 previous entries) and the maximum (22 previous entries) values of Host country experience. Accordingly, FMs' propensity to make greenfield initiatives is $24.25 \%$ higher than that of non-FFs when both have no international experience. This greater preference holds stable along the entire range of host country experience, and it reaches $22.85 \%$ when both types of firms have 22 previous foreign entries in the same country. As 
predicted, the effect is stronger for FOs because they are $21.15 \%$ more likely than non-FFs to establish a greenfield investment when both have no previous experience (a percentage comparable to that of FMs). However, as the experience in the host country increases, it has an exacerbating effect on the propensity toward acquisitions, as long as they undertake $21.78 \%$ less greenfield initiatives than nonFFs when experience is at its maximum in our sample. To summarize, although a reduction in the noted propensity can be observed in all the firm categories when the host country experience increases, a large gap exists between FOs and the other two categories, with the former definitely more sensitive to a variation in international experience. These differences are significant at any conventionally accepted statistical threshold, thus supporting hypothesis 2 .

\section{Robustness check on the role of the ownership choice}

To corroborate the results, we must rule out that the establishment mode choice is actually intertwined with the ownership choice in the foreign subsidiary and that the latter is inherently different for nonFFs, FOs, and FMs. In fact, relying on an international partner can be an effective way to share the risk of entry and obtain country-specific information and knowledge (Mariotti, Piscitello, \& Elia, 2014). Thus, although joint ventures and other minority partnerships are viable both in acquisitions and in greenfield operations ${ }^{14}$, their influence on the establishment mode choice deserves to be investigated because the literature proposes opposing views: Hennart \& Park (1993) argue that there is no relationship between the ownership and the establishment mode choices; other scholars (e.g., Kogut $\&$ Singh, 1988) suggest that such a relationship exists and should be properly taken into account.

Thus, we model the control and the establishment mode choice as a joint decision and create four combinations: Acquisition \& Minority, Acquisition \& Majority, Greenfield \& Minority, and Greenfield $\&$ Majority, where minority (majority) means that the equity stake is lower than or equal to (higher than) $50 \%$. The new dependent variable then takes four values, according to the mentioned classes, while the explanatory variables remain those illustrated in the previous section. The four classes cannot be ordered; however, they are mutually exclusive and exhaustive with regard to the aim of this 
work; therefore, we run multinomial logit with firm-level clustered standard errors. Econometric findings are reported in Table 6.

[insert Table 6 about here]

With no loss of generality, we choose Greenfield \& Majority as the baseline model, meaning that estimated coefficients must be interpreted as deviations from the base level. In the first four columns of Table 6, we present the analyses that incorporate the standard controls, FO and FM (i.e., hypothesis 1). Examining the Greenfield \& Minority column, we see that there is no significant impact of FO and FM. In other words, the impact of FO and FM does not change when the stake owned in a greenfield investment is a majority rather than a minority one. Similarly, both categories of acquisitions (i.e., Acquisition \& Majority and Acquisition \& Minority) are negatively influenced by family owned and family managed, thus showing that, regardless of the ownership choice, both FOs and FMs undertake fewer acquisitions (vs. greenfield) than non-FFs.

The last three columns of Table 6 also present the host country experience and its interaction with FO and FM (i.e., hypothesis 2). The base level is again Greenfield \& Majority. When we compare the base level with Greenfield \& Minority, we see that there is no difference in the main effects or in the interacted terms. Again, we can claim that FOs and FMs - also including their host country experience - do not behave differently according to the ownership choice in greenfield investments. Analogously, the interaction between FO and Host country experience is significant for both categories of acquisitions, while the interaction between FM and the latter is not. We then find support for the main finding in hypothesis 2 and rule out that the ownership choice in a foreign subsidiary varies among non-FFs, FOs, and FMs ${ }^{15}$.

\section{DISCUSSION}

Econometric findings support the arguments developed in this study. After controlling for deal-, firmand country-specific variables that IB literature has shown to drive MNEs' establishment mode choice, we find that the latter is significantly influenced by the degree of family involvement in the firm. 
Consistent with our first hypothesis, FFs entering a foreign country are more prone to establish a new venture rather than acquire an existing company, compared with their non-family counterparts. However, contrary to our expectations, FMs do not behave differently from FOs in their likelihood of preferring greenfield investments. This result suggests that commonalities between FOs and FMs are significantly stronger than dissimilarities because SEW-driven risk aversion characterizes both typologies of FFs, and it plays a key role in orienting the choice of establishment mode in foreign markets.

Our results also confirm that, consistent with the traditional IB literature, the accumulation of information stemming from previous presence in the same country negatively moderates the need and propensity toward greenfield entries for all the typologies of firms. However, the marginal effects of host country experience increase in FFs, namely being stronger in FOs. We relate this effect to the different information endowment that characterizes non-FFs vs. FFs. Non-FFs have a richer and more diversified shareholder and managerial base that a priori makes them well informed, so that additional international experience in the host country adds only marginally to their knowledge. In contrast, FFs lack solid international experience, and their perceived risk in acquiring abroad is higher, strengthening SEW worries about economic benefits of external growth decisions. Their risk aversion is mitigated only once they obtain specific international experience. However, FOs benefit more from this experience because their management is more equipped to absorb and leverage it. In FMs, in contrast, the absorption of specific international experience is inhibited or restrained by the lesser endowment of managerial capabilities, often exacerbated by the entrenchment effect.

Our results contribute to the academic debate about establishment mode studies (Hennart \& Slangen, 2014) but also have implications for practice. Specifically, we suggest that FFs can suffer from specific features of family business that reduce and/or constrain their decision-making options. To better capitalize on their competitive advantages in foreign contexts, FFs must carefully balance the risk of SEW dilution and owner-manager misalignment with greater involvement in the firm of external investors and managers that give the firm access to new knowledge and experience and mitigate the entrenchment effect. Indeed, FFs may achieve several advantages from opening up their 
governance to non-family experienced actors, such as smoothing internal orientation biases, improving the ability to manage complex operations under uncertain conditions, and developing a willingness to pursue less conservative strategies that are more based on the combination of both exploitation and exploration activities (Patel \& Chrisman, 2014).

\section{LIMITATIONS AND FUTURE RESEARCH}

As usual, the paper is not immune from limitations that, still, provide opportunities for future research. First, although we are aware that linking managerial choices or decision models to measurable performance outcomes is critical (Brouthers, 2013), we do not address whether the selected establishment mode is the right or the wrong choice in terms of performance. Unfortunately, the lack of information about performance metrics relevant to foreign investment currently hinders such empirical extensions. However, in spite of several works on the establishment mode choice, we still know little about the consequences of this choice, and such an extension ranks high on our research agenda.

Second, allowing for the ex-ante heterogeneity of MNEs in terms of their parents' performances could provide additional hints. For example, Nocke \& Yeaple (2007) show theoretically that cross-border acquisitions (compared with greenfield) involve either the most or the least efficient investing firms.

Third, the results on the relevance of host country experience encourage further investigation of its different components, especially the learning versus self-selection mechanisms associated with the repetition of successful/unsuccessful strategic choices, and related to either a specific host country or similar countries. However, and again, more detailed firm-level information would be needed, and its lack of availability currently hinders the noted avenues for development of the work.

We also acknowledge that family involvement is a broad and complex construct that is worth deep consideration. Thus, we call for more research on other facets of FF's heterogeneity, such as managerial structure and board of directors composition. Finally, although the Italian market is a particularly interesting context in which to study and compare FFs and non-FFs, the empirical setting 
can be fruitfully enlarged, e.g., by adding more countries to test the role of country specificities and generalize the results. Indeed, although we built the sample carefully, the number of non-FFs in some countries' investments is limited due to the relatively minimal presence of these firms in the Italian context. We ran several tests to ensure that this paucity did not affect the empirical findings; however, it would be interesting to investigate whether the results hold in countries with a lower share of FFs.

\section{ENDNOTES}

${ }^{1}$ FFs dominate not only in emerging economies, such as Asia (where they constitute approximately 95 percent of all firms), but also constitute 70 percent of all publicly traded firms in the US and almost half of the largest Fortune 1,000 firms.

${ }^{2}$ Even if a FF explores the opportunity to acquire a foreign firm, it will likely lose the competition on the international market for corporate control. Let us compare the competitive positions of two bidders, the focal FF and a non-FF. The more relevant information a firm has, the more correctly it assesses the risk of the acquisition. The non-FF is endowed with more information and is able to access and process further relevant information at lower cost. Furthermore, because family principals concentrate their wealth in the single FF, they do not generally benefit from wealth changes tied to other diversified assets and therefore err on the right-hand side of the risk distribution (i.e., they do not rely on the mean risk but rather something higher). Under conditions of lower information, wealth concentration and risk aversion, the FF faces a higher discount rate in obtaining the deal price; then, the non-FF will incrementally outbid the FF, and the transaction will result in an acquisition for the non-FF. If this continues (or the market for existing opportunities dies), then the FF will be forced to simply make a decision whether to establish a project from scratch, and the set of strategic alternative will be consequently constrained. We are particularly grateful to an anonymous reviewer for suggesting such an interpretation, which strengthens our hypothesis.

${ }^{3}$ To better clarify the point, let us return to the example of competition on the international market for corporate control (see note 2). Thanks to their more talented managers, when information arrives, FOs update their assessment of the riskiness of acquiring the target firm in the host country. Acquisition target prices are now more in line with those of non-FFs, and bidding is more competitive because of 
the better understanding and tolerance of risk. As a result, more acquisitions occur. In other words, in comparison with non-FFs, FOs experiment a stronger (negative) marginal effect on their propensity to choose greenfield investments.

${ }^{4}$ Firms operating in industries with 2-digit NACE codes from 10 to 33, according to the European Union classification of manufacturing firms.

${ }^{5}$ The choice of such high thresholds is justified because the Italian market for corporate control is characterized by large blockholdings (Miller et al., 2014).

${ }^{6}$ It is worth highlighting that the high share of FFs in our data set is not the result of a sampling bias but rather is a characteristic of the Italian economy, where FFs largely exceed their non-family counterparts.

${ }^{7}$ As one reviewer notes, it seems that there, non-FFs avoid investing in certain countries. We investigate this issue by interacting FOs and FMs with each of the country-level controls, and no particular bias seems to emerge with reference to the object of this study. The results are available from the authors upon request.

${ }^{8}$ We thank the editor and an anonymous reviewer for suggesting such a test to rule out endogeneity between the ownership and management choice and the establishment mode choice.

${ }^{9}$ We also specify the models without year fixed effects. The findings are comparable to those with such effects. Both the coefficients and marginal effects are reported in Appendix 2.

${ }^{10}$ The number of controls employed is high to rule out potential omitted variable endogeneity. However, we run additional models with varying numbers of controls to check the robustness of the results, and the main effects always hold. Sensitivity analyses with fewer controls are available from the authors upon request.

${ }^{11}$ It may be worth noting that, to analyze whether financial constraints have different effects for FOs and FMs, we interact the relevant dummy variables with leverage and cash flow on assets; however, the interaction terms never come out significant. The results are available upon request.

${ }^{12}$ To correspond to the debate in the IB literature, we also employ the index proposed by Kogut \& Singh (1988) and based on Hofstede's five dimensions of cultural distance. However, because the 
findings are similar in every model, we do not report the latter. Again, the results are available upon request.

${ }^{13}$ A complementary explanation relies upon the specific structure of control in Italian FFs, which exhibits high concentration, with families often acting as powerful blockholders (Miller et al., 2013). Under this condition, families can more closely monitor non-family managers through formal and moral suasion, thus easily aligning the firms' choices with their preferences.

${ }^{14}$ In our sample, the share of minority operations of the total is the same for greenfields and acquisitions (11.36\% vs. $11.44 \%$ - Table 1$)$.

${ }^{15}$ The Hausman-McFadden test on the irrelevance of independent alternatives (IIA) rejects the null hypothesis that omitting any category affects the ratio of the probabilities of choosing any pairs of alternatives, with a p-value lower than 0.01 . Furthermore, no category can collapse to others because the Wald test is always significant with p-values lower than 0.01 . 


\section{REFERENCES}

Ai, C., \& Norton, E. C. 2003. Interaction terms in logit and probit models. Economics Letters, 80(1): 123-129.

Allison, P. D. 1999. Comparing logit and probit coefficients across groups. Sociological Methods \& Research, 28(2): 186-208.

Anderson, R. C., \& Reeb, D. M. 2003. Founding-family ownership, corporate diversification, and firm leverage. Journal of Law and Economics, 46(2): 653-684.

Anderson, R. C., Duru, A., \& Reeb, D. M. 2009. Founders, heirs, and corporate opacity in the United States. Journal of Financial Economics, 92(2), 205-222.

Arregle, J. L., Naldi, L., Nordqvist, M., \& Hitt, M. A. 2012. Internationalization of family-controlled firms: A study of the effects of external involvement in governance. Entrepreneurship Theory and Practice, 36(6): 1115-1143.

Banalieva, E. R., \& Eddleston, K. A. 2011. Home-region focus and performance of family firms: The role of family vs non-family leaders. Journal of International Business Studies, 42(8): 1060-1072.

Berrone, P., Cruz, C., \& Gomez-Mejia, L. R., 2012. Socioemotional wealth in family firms: Theoretical dimensions, assessment approaches, and agenda for future research. Family Business Review, 25(3): 258-279.

Bertrand, M., \& Schoar, A. 2006. The role of family in family firms. Journal of Economic Perspectives, 20(2): 73-96.

Brouthers, K. D. 2013. A retrospective on: Institutional, cultural and transaction cost influences on entry mode choice and performance. Journal of International Business Studies, 44(1): 14-22.

Brouthers, K. D., \& Brouthers, L. E. 2000. Acquisition or greenfield start-up? Institutional, cultural and transaction cost influences. Strategic Management Journal, 21(1): 89-97.

Brouthers, K.D. \& Dikova, D. 2010. Acquisitions and real options: The greenfield alternative. Journal of Management Studies, 47(6): 1048-1071.

Caprio, L., Croci, E. \& Del Giudice, A. 2011. Ownership structures, family control, and acquisition decisions. Journal of Corporate Finance, 17(5): 1636-1657. 
Chua, J. H., Chrisman, J. J., Steier, L. P., \& Rau, S. B. 2012. Sources of heterogeneity in family firms: An introduction. Entrepreneurship Theory and Practice, 36(6): 1103-1113.

Cumming, D., Knill, A., \& Syvrud, K. 2016. Do international investors enhance private firm value? Evidence from venture capital. Journal of International Business Studies, advance online publication January 14. doi:10.1057/jibs.2015.46.

Dow, D., \& Karunaratna, A. 2006. Developing a multidimensional instrument to measure psychic distance stimuli. Journal of International Business Studies, 37(5): 578-602.

Dow, D., \& Larimo, J. 2011. Disentangling the roles of international experience and distance in establishment mode choice. Management International Review, 51(3): 321-355.

Faccio, M., Marchica, M.T., \& Mura, R. 2011. Large shareholder diversification and corporate risktaking. Review of Financial Studies, 24(11): 3601-3641.

Fernandez, Z., \& Nieto, M. J. 2006. Impact of ownership on the international involvement of SMEs. Journal of International Business Studies, 37(3): 340-351.

Furfine, C. H, \& Rosen, R. J. 2011. Mergers increase default risk. Journal of Corporate Finance, 17(4):832-849.

Gomez-Mejia, L. R., Makri, M., \& Kintana, M. L. 2010. Diversification decisions in family-controlled firms. Journal of Management Studies, 47(2): 223-252.

Hair, J., Black, W. C., Babin, B. J., \& Anderson, R. E. 2010. Multivariate data analysis. Upper Saddle River: Pearson Education International.

Hennart, J. F., \& Park, Y. R. 1993. Greenfield vs. acquisition: The strategy of Japanese investors in the United States. Management Science, 39(9): 1054-1070.

Hennart, J. F., \& Slangen, A. H. 2014. Yes, we really do need more entry mode studies! A commentary on Shaver. Journal of International Business Studies, 46(1): 114-122.

Hoetker, G. 2007. The use of logit and probit models in strategic management research: Critical issues. Strategic Management Journal, 28(4): 331-343.

Kogut, B., \& Singh, H. 1988. The effect of national culture on the choice of entry mode. Journal of International Business Studies, 19(3): 411-432. 
Koropp, C., Kellermanns, F. W., Grichnik, D., \& Stanley, L. 2014. Financial decision making in family firms. An adaptation of the theory of planned behavior. Family Business Review, 27(4): $307-327$.

Levy, O., Beechler, S., Taylor, S., \& Boyacigiller, N. A. 2007. What we talk about when we talk about 'global mindset': Managerial cognition in multinational corporations. Journal of International Business Studies, 38(2): 231-258.

Maitland, E., \& Sammartino, A. 2015. Managerial cognition and internationalization. Journal of International Business Studies, 46(7): 733-760.

Malhotra, S., \& Gaur, A. S. 2013. Spatial geography and control in foreign acquisitions. Journal of International Business Studies, 45(2): 191-210.

Martynova, M., \& Renneboog, L. D. R. 2009. What determines the financing decision in corporate takeovers: Cost of capital, agency problems, or the means of payment? Journal of Corporate Finance, 15(3): 290-315.

Mariotti, S., Mutinelli, M., \& Sansoucy, L. 2015. Italia multinazionale 2014: Le partecipazioni italiane all'estero ed estere in Italia. Soveria Mannelli: Rubbettino Editore.

Mariotti, S., Piscitello, L., \& Elia, S. 2014. Local externalities and ownership choices in foreign acquisitions by multinational enterprises. Economic Geography, 90(2): 187-211.

Menon, T., \& Pfeffer, J. 2003. Valuing internal vs. external knowledge: Explaining the preference for outsiders. Management Science, 49(4): 497-513.

Miller, D., Le Breton-Miller, I., \& Lester, R. H. 2010. Family ownership and acquisition behavior in publicly-traded companies. Strategic Management Journal, 31(2): 201-223.

Miller, D., Minichilli, A., \& Corbetta, G. 2013. Is family leadership always beneficial?. Strategic Management Journal, 34(5): 553-571.

Miller, D., Le Breton-Miller, I., Minichilli, A., Corbetta, G., \& Pittino, D. 2014. When do non-family CEOs outperform in family firms? Agency and behavioural agency perspectives. Journal of Management Studies, 51(4): 547-572. 
Musteen, M., Datta, D. K., \& Herrmann, P. 2009. Ownership structure and CEO compensation: Implications for the choice of foreign market entry modes. Journal of International Business Studies, 40(2): 321-338.

Nocke, V., \& Yeaple, S. 2007. Cross-border mergers and acquisitions vs. greenfield foreign direct investment: The role of firm heterogeneity. Journal of International Economics, 72(2): 336-365.

Padmanabhan, P., \& Cho, K. R. 1999. Decision specific experience in foreign ownership and establishment strategies: Evidence from Japanese firms. Journal of International Business Studies, 30(1): 25-41.

Patel, P. C., \& Chrisman, J. J. 2014. Risk abatement as a strategy for R\&D investments in family firms. Strategic Management Journal, 35(4): 617-627.

Reiche, B. S., Harzing, A. W., \& Pudelko, M. 2015. Why and how does shared language affect subsidiary knowledge inflows? A social identity perspective. Journal of International Business Studies, 46(5): 528-551.

Reuer, J. J., \& Ragozzino, R. 2014. Signals and international alliance formation: The roles of affiliations and international activities. Journal of International Business Studies, 45(3): 321-337.

Shenkar, O. (2001). Cultural distance revisited: Towards a more rigorous conceptualization and measurement of cultural differences. Journal of International Business Studies, 32(3): 519-535.

Siegel, D. S., \& Simons, K. L. 2010, Assessing the effects of mergers and acquisitions on firm performance, plant productivity, and workers: New evidence from matched employer-employee data. Strategic Management Journal, 31(8): 903-916.

Singla, C., Veliyath, R., \& George, R. 2014. Family firms and internationalization-governance relationships: Evidence of secondary agency issues. Strategic Management Journal, 35(4): 606616.

Slangen, A., \& Hennart, J. F. 2007. Greenfield or acquisition entry: A review of the empirical foreign establishment mode literature. Journal of International Management, 13(4): 403-429.

Strange, R., Filatotchev, I., Buck, T., \& Wright, M. 2009. Corporate governance and international business. Management International Review, 49(4): 395-407. 
Strike, V. M., Berrone, P., Sapp, S., \& Congiu, L. 2015. A socioemotional wealth approach to CEO career horizons in family firms. Journal of Management Studies, 52(4): 555-583.

Tihanyi, L., Johnson, R. A., Hoskisson, R. E., \& Hitt, M. A. 2003. Institutional ownership differences and international diversification: The effects of boards of directors and technological opportunity. Academy of Management Journal, 46(2): 195-211.

Zaheer, S. 1995. Overcoming the liability of foreignness. Academy of Management Journal, 38(2): 341-363. 
TABLES AND FIGURES

Table 1. Summary statistics.

\begin{tabular}{|c|c|c|c|c|c|c|c|c|}
\hline & non-FFs & $\%$ & FOs & $\%$ & FMs & $\%$ & Total & $\%$ \\
\hline Firms (no.) & 29 & & 69 & & 213 & & 311 & \\
\hline Average size (no. of employees) & 567 & & 786 & & 799 & & 768 & \\
\hline Foreign entries (no.) & 124 & 100.00 & 272 & 100.00 & 649 & 100.00 & 1,045 & 100.00 \\
\hline Greenfield & 39 & 31.45 & 175 & 64.34 & 420 & 64.71 & 634 & 60.67 \\
\hline Majority (> 50\%) & 29 & 74.36 & 156 & 89.14 & 377 & 89.76 & 562 & 88.64 \\
\hline Minority ( $\leq 50 \%)$ & 10 & 25.64 & 19 & 10.86 & 43 & 10.24 & 72 & 11.36 \\
\hline Acquisition & 85 & 68.55 & 97 & 35.66 & 229 & 35.29 & 411 & 39.33 \\
\hline Majority (> 50\%) & 70 & 82.35 & 93 & 95.88 & 201 & 87.77 & 364 & 88.56 \\
\hline Minority ( $\leq 50 \%)$ & 15 & 17.65 & 4 & 4.12 & 28 & 12.23 & 47 & 11.44 \\
\hline Average foreign entries per firm & 4.28 & & 3.94 & & 3.05 & & 3.36 & \\
\hline Greenfield & 1.35 & & 2.54 & & 1.97 & & 2.04 & \\
\hline Acquisition & 2.93 & & 1.41 & & 1.08 & & 1.32 & \\
\hline $\begin{array}{l}\text { Share of foreign entries preceded by } \\
\text { another investment in the same host } \\
\text { country by the same parent firm (\%) }\end{array}$ & 45.16 & & 22.79 & & 24.65 & & 26.60 & \\
\hline Greenfield & 43.59 & & 11.43 & & 17.86 & & 17.67 & \\
\hline Acquisition & 45.88 & & 43.30 & & 37.12 & & 40.39 & \\
\hline
\end{tabular}


Table 2: Foreign entries distribution by country.

\begin{tabular}{|c|c|c|c|c|c|c|c|c|}
\hline \multirow[t]{2}{*}{ Country } & \multicolumn{2}{|c|}{ non-FFs } & \multicolumn{2}{|c|}{ FOs } & \multicolumn{2}{|c|}{ FMs } & \multicolumn{2}{|c|}{ Total } \\
\hline & $\begin{array}{c}\text { Foreign } \\
\text { entries (no.) }\end{array}$ & $\begin{array}{c}\text { Greenfield } \\
(\%)\end{array}$ & $\begin{array}{c}\text { Foreign } \\
\text { entries (no.) }\end{array}$ & $\begin{array}{l}\text { Greenfield } \\
(\%)\end{array}$ & $\begin{array}{c}\text { Foreign } \\
\text { entries (no.) }\end{array}$ & $\begin{array}{l}\text { Greenfield } \\
(\%)\end{array}$ & $\begin{array}{c}\text { Foreign } \\
\text { entries (no.) }\end{array}$ & $\begin{array}{l}\text { Greenfield } \\
(\%)\end{array}$ \\
\hline China & 21 & 66.67 & 28 & 89.29 & 103 & 76.70 & 152 & 77.63 \\
\hline $\begin{array}{l}\text { United } \\
\text { States }\end{array}$ & 31 & 16.13 & 29 & 41.38 & 49 & 57.14 & 109 & 41.28 \\
\hline Germany & 11 & 9.09 & 17 & 58.82 & 60 & 48.33 & 88 & 45.45 \\
\hline France & 4 & 25.00 & 14 & 42.86 & 50 & 46.00 & 68 & 44.12 \\
\hline $\begin{array}{l}\text { United } \\
\text { Kingdom }\end{array}$ & 11 & 9.09 & 24 & 29.17 & 33 & 51.52 & 68 & 36.76 \\
\hline India & 1 & 100.00 & 13 & 76.92 & 36 & 83.33 & 50 & 82.00 \\
\hline Poland & 8 & 50.00 & 4 & 50.00 & 28 & 78.57 & 40 & 70.00 \\
\hline Russia & 5 & 60.00 & 14 & 85.71 & 19 & 94.74 & 38 & 86.84 \\
\hline Brazil & 3 & 0.00 & 16 & 50.00 & 18 & 77.78 & 37 & 59.46 \\
\hline Spain & 4 & 0.00 & 8 & 87.50 & 25 & 56.00 & 37 & 56.76 \\
\hline Switzerland & 3 & 33.33 & 4 & 75.00 & 20 & 50.00 & 27 & 51.85 \\
\hline Hong Kong & 1 & 100.00 & 5 & 100.00 & 20 & 75.00 & 26 & 80.77 \\
\hline Belgium & 2 & 0.00 & 5 & 100.00 & 16 & 43.75 & 23 & 52.17 \\
\hline Netherlands & 4 & 25.00 & 7 & 100.00 & 7 & 42.86 & 18 & 61.11 \\
\hline Austria & 1 & 0.00 & 11 & 54.55 & 4 & 75.00 & 16 & 56.25 \\
\hline Portugal & 1 & 0.00 & 2 & 50.00 & 12 & 58.33 & 15 & 53.33 \\
\hline Turkey & 3 & 66.67 & 1 & 100.00 & 11 & 63.64 & 15 & 66.67 \\
\hline $\begin{array}{l}\text { Other } \\
\text { countries }\end{array}$ & 10 & 40.00 & 70 & 68.57 & 138 & 68.12 & 218 & 66.97 \\
\hline Total & 124 & 31.45 & 272 & 64.34 & 649 & 64.71 & 1,045 & 60.67 \\
\hline
\end{tabular}


Table 3. Descriptive statistics ( $N=1,045)$.

\begin{tabular}{|c|c|c|c|c|c|c|c|c|c|c|c|c|c|c|c|c|c|c|c|c|c|c|c|}
\hline & & Mean & S.D. & (1) & (2) & (3) & (4) & (5) & (6) & (7) & (8) & (9) & (10) & (11) & (12) & (13) & (14) & (15) & (16) & (17) & (18) & (19) & (20) \\
\hline (1) & $\begin{array}{l}\text { Establishment mode } \\
\text { choice }\end{array}$ & 0.61 & 0.49 & & & & & & & & & & & & & & & & & & & & \\
\hline (2) & Family owned & 0.26 & 0.44 & 0.05 & & & & & & & & & & & & & & & & & & & \\
\hline \multirow{2}{*}{$\begin{array}{l}\text { (3) } \\
\text { (4) }\end{array}$} & Family managed & 0.62 & 0.49 & 0.11 & -0.76 & & & & & & & & & & & & & & & & & & \\
\hline & $\begin{array}{l}\text { Host country } \\
\text { experience }\end{array}$ & 0.91 & 2.61 & -0.23 & -0.07 & -0.16 & & & & & & & & & & & & & & & & & \\
\hline (5) & Horizontal expansion & 0.44 & 0.50 & -0.16 & -0.14 & -0.07 & 0.09 & & & & & & & & & & & & & & & & \\
\hline (6) & Vertical expansion & 0.05 & 0.22 & -0.04 & -0.01 & -0.05 & -0.04 & -0.20 & & & & & & & & & & & & & & & \\
\hline (7) & Diversification & 0.03 & 0.16 & -0.09 & -0.04 & 0.02 & 0.07 & -0.04 & -0.14 & & & & & & & & & & & & & & \\
\hline (8) & Parent size & 5.79 & 1.80 & 0.10 & -0.14 & 0.16 & 0.15 & 0.04 & -0.02 & -0.01 & & & & & & & & & & & & & \\
\hline (9) & Parent age & 38.06 & 29.29 & -0.06 & -0.01 & 0.13 & 0.11 & 0.01 & -0.04 & 0.14 & 0.24 & & & & & & & & & & & & \\
\hline (10) & Parent diversification & 1.62 & 0.89 & 0.01 & 0.14 & -0.08 & -0.06 & 0.00 & -0.03 & -0.09 & -0.13 & -0.26 & & & & & & & & & & & \\
\hline (11) & Labor cost & 0.19 & 0.25 & -0.06 & 0.09 & -0.04 & -0.02 & -0.05 & -0.02 & -0.01 & -0.32 & -0.04 & 0.14 & & & & & & & & & & \\
\hline (12) & Listed & 0.35 & 0.48 & -0.05 & 0.11 & 0.07 & 0.06 & 0.03 & -0.21 & -0.00 & 0.13 & 0.20 & 0.00 & 0.18 & & & & & & & & & \\
\hline (13) & Leverage & 1.19 & 5.21 & 0.06 & 0.07 & -0.10 & -0.04 & -0.01 & -0.01 & -0.01 & -0.06 & -0.01 & -0.02 & -0.02 & -0.04 & & & & & & & & \\
\hline (14) & Cash flow on assets & 0.02 & 1.03 & -0.02 & -0.08 & 0.07 & 0.01 & 0.01 & -0.02 & -0.02 & 0.06 & -0.02 & -0.20 & 0.01 & 0.06 & 0.00 & & & & & & & \\
\hline (15) & Psychic distance & 1.60 & 1.65 & 0.22 & -0.07 & 0.08 & -0.08 & -0.01 & 0.23 & 0.04 & 0.02 & 0.05 & -0.04 & 0.02 & 0.01 & 0.03 & -0.00 & & & & & & \\
\hline (16) & Geographic distance & 8.03 & 0.95 & 0.14 & 0.02 & -0.04 & 0.04 & -0.03 & 0.14 & 0.04 & -0.08 & -0.01 & -0.02 & 0.10 & 0.03 & -0.01 & -0.04 & 0.62 & & & & & \\
\hline (17) & GDP growth & 0.04 & 0.04 & 0.23 & -0.04 & 0.06 & -0.16 & -0.02 & 0.15 & 0.04 & 0.02 & -0.06 & 0.00 & -0.00 & -0.05 & 0.01 & 0.01 & 0.74 & 0.43 & & & & \\
\hline (18) & GDP per capita & 9.48 & 1.35 & -0.25 & 0.02 & -0.06 & 0.15 & 0.02 & -0.23 & -0.02 & -0.01 & -0.02 & -0.00 & 0.00 & 0.04 & -0.03 & -0.00 & -0.58 & -0.48 & -0.68 & & & \\
\hline (19) & Market capitalization & 4.23 & 0.74 & -0.03 & -0.01 & -0.01 & 0.09 & 0.03 & -0.09 & -0.05 & 0.03 & 0.01 & 0.02 & 0.07 & 0.04 & -0.03 & -0.01 & -0.11 & 0.13 & 0.31 & 0.04 & & \\
\hline (20) & $\begin{array}{l}\text { Time to start a new } \\
\text { business }\end{array}$ & 0.22 & 0.23 & 0.11 & 0.04 & -0.02 & -0.10 & -0.02 & 0.11 & 0.02 & -0.13 & 0.00 & -0.01 & 0.01 & -0.02 & 0.02 & -0.08 & 0.43 & 0.31 & -0.50 & -0.22 & 0.29 & \\
\hline (21) & Economic freedom & 0.67 & 0.11 & -0.19 & 0.01 & -0.04 & 0.10 & 0.01 & -0.19 & -0.04 & -0.02 & -0.05 & 0.04 & 0.05 & 0.03 & -0.03 & 0.01 & -0.66 & -0.24 & 0.18 & 0.42 & -0.54 & -0.54 \\
\hline
\end{tabular}


Table 4. Probit models. Dependent variable: Establishment mode choice (greenfield $=1)$.

\begin{tabular}{|c|c|c|c|c|}
\hline & $(1)$ & $(2)$ & (3) & $(4)$ \\
\hline \multicolumn{5}{|l|}{ Main explanatory variables } \\
\hline Family owned & & $\begin{array}{c}0.87^{* * * *} \\
(0.25)\end{array}$ & $\begin{array}{l}0.74^{* * *} \\
(0.24)\end{array}$ & $\begin{array}{l}0.65^{* *} \\
(0.25)\end{array}$ \\
\hline Family managed & & $\begin{array}{c}0.86^{* * * *} \\
(0.20)\end{array}$ & $\begin{array}{c}0.72^{* * *} \\
(0.19)\end{array}$ & $\begin{array}{c}0.74^{* * * *} \\
(0.19)\end{array}$ \\
\hline Host country experience & & & $\begin{array}{l}-0.08^{*} \\
(0.03)\end{array}$ & $\begin{array}{l}-0.05^{*} \\
(0.02)\end{array}$ \\
\hline \multicolumn{5}{|l|}{ Interaction effects } \\
\hline \multirow[t]{2}{*}{ Family owned $x$ Host country experience } & & & & $-0.24^{*}$ \\
\hline & & & & $\begin{array}{c}(0.12) \\
0.00\end{array}$ \\
\hline Family managed $x$ Host country experience & & & & $(0.05)$ \\
\hline \multicolumn{5}{|l|}{ Deal-level controls } \\
\hline Horizontal expansion & $\begin{array}{c}-0.84^{* * * *} \\
(0.12)\end{array}$ & $\begin{array}{c}-0.72^{* * * *} \\
(0.12)\end{array}$ & $\begin{array}{c}-0.73^{* * *} \\
(0.12)\end{array}$ & $\begin{array}{c}-0.73^{* * * *} \\
(0.12)\end{array}$ \\
\hline Vertical expansion & $\begin{array}{c}-0.62^{* *} \\
(0.24)\end{array}$ & $\begin{array}{l}-0.49^{*} \\
(0.21)\end{array}$ & $\begin{array}{l}-0.54^{*} \\
(0.22)\end{array}$ & $\begin{array}{l}-0.54^{*} \\
(0.22)\end{array}$ \\
\hline Diversification & $\begin{array}{l}-1.18^{*} \\
(0.58)\end{array}$ & $\begin{array}{l}-1.11^{\dagger} \\
(0.59)\end{array}$ & $\begin{array}{l}-1.09^{*} \\
(0.54)\end{array}$ & $\begin{array}{l}-1.08^{*} \\
(0.54)\end{array}$ \\
\hline \multicolumn{5}{|l|}{ Parent-level controls } \\
\hline Parent size & $\begin{array}{c}0.08^{\dagger} \\
(0.04)\end{array}$ & $\begin{array}{l}0.08^{*} \\
(0.04)\end{array}$ & $\begin{array}{l}0.09^{*} \\
(0.04)\end{array}$ & $\begin{array}{l}0.10^{* * *} \\
(0.04)\end{array}$ \\
\hline Parent age & $\begin{array}{l}-0.00 \\
(0.00)\end{array}$ & $\begin{array}{l}-0.00 \\
(0.00)\end{array}$ & $\begin{array}{l}-0.00 \\
(0.00)\end{array}$ & $\begin{array}{l}-0.00 \\
(0.00)\end{array}$ \\
\hline Parent diversification & $\begin{array}{l}-0.06 \\
(0.08)\end{array}$ & $\begin{array}{l}-0.07 \\
(0.08)\end{array}$ & $\begin{array}{l}-0.06 \\
(0.08)\end{array}$ & $\begin{array}{l}-0.04 \\
(0.08)\end{array}$ \\
\hline Labor intensity & $\begin{array}{c}0.01 \\
(0.22)\end{array}$ & $\begin{array}{l}-0.06 \\
(0.21)\end{array}$ & $\begin{array}{l}-0.06 \\
(0.21)\end{array}$ & $\begin{array}{l}-0.08 \\
(0.21)\end{array}$ \\
\hline Listed & $\begin{array}{l}-0.45^{* *} \\
(0.17)\end{array}$ & $\begin{array}{l}-0.56^{* *} \\
(0.17)\end{array}$ & $\begin{array}{c}-0.52^{* * *} \\
(0.17)\end{array}$ & $\begin{array}{c}-0.52^{* *} \\
(0.17)\end{array}$ \\
\hline Leverage & $\begin{array}{c}0.02 \\
(0.02)\end{array}$ & $\begin{array}{c}0.02 \\
(0.02)\end{array}$ & $\begin{array}{c}0.02 \\
(0.02)\end{array}$ & $\begin{array}{c}0.02 \\
(0.02)\end{array}$ \\
\hline Cash flow on assets & $\begin{array}{l}-0.05 \\
(0.04)\end{array}$ & $\begin{array}{l}-0.03 \\
(0.04)\end{array}$ & $\begin{array}{l}-0.03 \\
(0.04)\end{array}$ & $\begin{array}{l}-0.02 \\
(0.04)\end{array}$ \\
\hline \multicolumn{5}{|l|}{ Country-level controls } \\
\hline Psychic distance & $\begin{array}{l}-0.00 \\
(0.07)\end{array}$ & $\begin{array}{c}0.01 \\
(0.07)\end{array}$ & $\begin{array}{c}0.01 \\
(0.07)\end{array}$ & $\begin{array}{c}0.01 \\
(0.07)\end{array}$ \\
\hline Geographic distance & $\begin{array}{c}0.10 \\
(0.07)\end{array}$ & $\begin{array}{c}0.11 \\
(0.07)\end{array}$ & $\begin{array}{c}0.11 \\
(0.07)\end{array}$ & $\begin{array}{c}0.11 \\
(0.07)\end{array}$ \\
\hline GDP growth & $\begin{array}{c}3.60 \\
(2.26)\end{array}$ & $\begin{array}{c}3.69 \\
(2.27)\end{array}$ & $\begin{array}{c}3.44 \\
(2.26)\end{array}$ & $\begin{array}{c}3.69 \\
(2.30)\end{array}$ \\
\hline GDP per capita & $\begin{array}{l}-0.23^{*} \\
(0.10)\end{array}$ & $\begin{array}{l}-0.21^{*} \\
(0.10)\end{array}$ & $\begin{array}{l}-0.19^{*} \\
(0.10)\end{array}$ & $\begin{array}{l}-0.19^{\dagger} \\
(0.10)\end{array}$ \\
\hline Market capitalization & $\begin{array}{l}-0.03 \\
(0.09)\end{array}$ & $\begin{array}{l}-0.03 \\
(0.09)\end{array}$ & $\begin{array}{l}-0.01 \\
(0.09)\end{array}$ & $\begin{array}{l}-0.00 \\
(0.09)\end{array}$ \\
\hline Time to start a new business & $\begin{array}{l}-0.05 \\
(0.26)\end{array}$ & $\begin{array}{l}-0.05 \\
(0.27)\end{array}$ & $\begin{array}{l}-0.07 \\
(0.26)\end{array}$ & $\begin{array}{l}-0.01 \\
(0.26)\end{array}$ \\
\hline Economic freedom & $\begin{array}{c}0.25 \\
(0.81)\end{array}$ & $\begin{array}{c}0.34 \\
(0.81)\end{array}$ & $\begin{array}{c}0.04 \\
(0.81)\end{array}$ & $\begin{array}{c}0.16 \\
(0.83)\end{array}$ \\
\hline Constant & $\begin{array}{c}1.68 \\
(1.07)\end{array}$ & $\begin{array}{c}0.62 \\
(1.10)\end{array}$ & $\begin{array}{c}0.38 \\
(1.06)\end{array}$ & $\begin{array}{c}0.21 \\
(1.06)\end{array}$ \\
\hline Industry fixed effects & Yes & Yes & Yes & Yes \\
\hline Year fixed effects & Yes & Yes & Yes & Yes \\
\hline Observations & 1,045 & 1,045 & 1,045 & 1,045 \\
\hline $\mathrm{FO}=\mathrm{FM}(\mathrm{p}$-value $)$ & & 0.94 & 0.90 & 0.61 \\
\hline Efron's pseudo $\mathrm{R}^{2}$ & $23.5 \%$ & $25.5 \%$ & $26.2 \%$ & $26.9 \%$ \\
\hline Ratio of correct classifications & $71.96 \%$ & $73.30 \%$ & $73.40 \%$ & $74.26 \%$ \\
\hline $\begin{array}{l}\text { Wald test }{ }^{a} \\
\text { (degrees of freedom) }\end{array}$ & & $\begin{array}{l}19.52^{* * * *} \\
(2)\end{array}$ & $\begin{array}{l}27.77^{* * * *} \\
(3)\end{array}$ & $\begin{array}{c}40.08^{* * * *} \\
(5)\end{array}$ \\
\hline
\end{tabular}

(dreedom)

Note:

Firm-level clustered standard errors in parentheses

${ }^{\dagger} p<0.10,{ }^{*} p<0.05,{ }^{* * *} p<0.01,{ }^{* * *} p<0.001$

${ }^{a}$ Reference model is (1) 
Table 5. Average marginal effects. Dependent variable: Establishment mode choice (greenfield $=1)$.

\begin{tabular}{|c|c|c|c|c|}
\hline & $(1)$ & $(2)$ & (3) & (4) \\
\hline \multicolumn{5}{|l|}{ Main explanatory variables } \\
\hline \multirow{2}{*}{ Family owned } & & $0.28^{* * *}$ & $0.24^{* *}$ & $0.23^{* *}$ \\
\hline & & $(0.08)$ & $(0.07)$ & $(0.07)$ \\
\hline \multirow[t]{2}{*}{ Family managed } & & $0.27^{* * * *}$ & $0.23^{* * * *}$ & $0.24^{* * *}$ \\
\hline & & $(0.06)$ & $(0.06)$ & $(0.06)$ \\
\hline \multirow[t]{2}{*}{ Host country experience } & & & $-0.02^{*}$ & $-0.03^{* *}$ \\
\hline & & & $(0.01)$ & $(0.01)$ \\
\hline \multicolumn{5}{|l|}{ Deal-level controls } \\
\hline \multirow[t]{2}{*}{ Horizontal expansion } & $-0.26^{* * * *}$ & $-0.22^{* * *}$ & $-0.22^{* * *}$ & $-0.22^{* * *}$ \\
\hline & $(0.03)$ & $(0.03)$ & $(0.03)$ & $(0.03)$ \\
\hline \multirow[t]{2}{*}{ Vertical expansion } & $-0.19^{* *}$ & $-0.15^{*}$ & $-0.16^{* * *}$ & $-0.16^{* *}$ \\
\hline & $(0.07)$ & $(0.06)$ & $(0.06)$ & $(0.06)$ \\
\hline \multirow[t]{2}{*}{ Diversification } & $-0.36^{*}$ & $-0.34^{\dagger}$ & $-0.33^{*}$ & $-0.32^{*}$ \\
\hline & $(0.17)$ & $(0.17)$ & $(0.15)$ & $(0.16)$ \\
\hline \multicolumn{5}{|l|}{ Parent-level controls } \\
\hline \multirow[t]{2}{*}{ Parent size } & $0.02^{\dagger}$ & $0.02^{*}$ & $0.03^{*}$ & $0.03^{* *}$ \\
\hline & $(0.01)$ & $(0.01)$ & $(0.01)$ & $(0.01)$ \\
\hline \multirow[t]{2}{*}{ Parent age } & -0.00 & -0.00 & -0.00 & -0.00 \\
\hline & $(0.00)$ & $(0.00)$ & $(0.00)$ & 0.00 \\
\hline \multirow[t]{2}{*}{ Parent diversification } & -0.02 & -0.02 & -0.02 & -0.01 \\
\hline & $(0.03)$ & $(0.02)$ & $(0.02)$ & $(0.02)$ \\
\hline \multirow[t]{2}{*}{ Labor intensity } & 0.00 & -0.02 & -0.02 & -0.02 \\
\hline & $(0.07)$ & $(0.06)$ & $(0.06)$ & $(0.06)$ \\
\hline \multirow[t]{2}{*}{ Listed } & $-0.14^{* * *}$ & $-0.17^{* * * *}$ & $-0.16^{* * *}$ & $-0.15^{* *}$ \\
\hline & $(0.05)$ & $(0.05)$ & $(0.05)$ & $(0.05)$ \\
\hline \multirow[t]{2}{*}{ Leverage } & 0.00 & 0.01 & 0.00 & 0.00 \\
\hline & $(0.01)$ & $(0.01)$ & $(0.01)$ & $(0.00)$ \\
\hline \multirow[t]{2}{*}{ Cash flow on assets } & -0.02 & -0.01 & -0.01 & -0.01 \\
\hline & $(0.01)$ & $(0.01)$ & $(0.01)$ & $(0.01)$ \\
\hline \multicolumn{5}{|l|}{ Country-level controls } \\
\hline \multirow[t]{2}{*}{ Psychic distance } & -0.00 & 0.00 & 0.00 & 0.00 \\
\hline & $(0.02)$ & $(0.02)$ & $(0.02)$ & 0.02 \\
\hline \multirow[t]{2}{*}{ Geographic distance } & 0.03 & 0.03 & $0.03^{\dagger}$ & 0.03 \\
\hline & $(0.02)$ & $(0.02)$ & $(0.02)$ & 0.02 \\
\hline \multirow[t]{2}{*}{ GDP growth } & 1.12 & 1.12 & 1.03 & 1.10 \\
\hline & $(0.70)$ & $(0.68)$ & $(0.67)$ & $(0.67)$ \\
\hline \multirow[t]{2}{*}{ GDP per capita } & $-0.07^{*}$ & $-0.06^{*}$ & $-0.06^{*}$ & $-0.06^{*}$ \\
\hline & $(0.03)$ & $(0.03)$ & $(0.03)$ & $(0.03)$ \\
\hline \multirow[t]{2}{*}{ Market capitalization } & -0.01 & -0.01 & -0.00 & -0.00 \\
\hline & $(0.03)$ & $(0.03)$ & $(0.03)$ & $(0.03)$ \\
\hline \multirow[t]{2}{*}{ Time to start a new business } & -0.01 & -0.02 & -0.02 & -0.00 \\
\hline & $(0.08)$ & $(0.08)$ & $(0.08)$ & $(0.08)$ \\
\hline Economic freedom & 0.08 & 0.10 & 0.01 & 0.05 \\
\hline & $(0.25)$ & $(0.25)$ & $(0.24)$ & $(0.25)$ \\
\hline Industry fixed effects & Yes & Yes & Yes & Yes \\
\hline Year fixed effects & Yes & Yes & Yes & Yes \\
\hline Observations & 1,045 & 1,045 & 1,045 & 1,045 \\
\hline
\end{tabular}


Table 6. Robustness checks. Multinomial logit models. Dependent variable in table header.

\begin{tabular}{|c|c|c|c|c|c|c|}
\hline & $\begin{array}{c}\text { Greenfield \& } \\
\text { Minority }\end{array}$ & $\begin{array}{l}\text { Acquisition } \\
\text { \& Majority }\end{array}$ & $\begin{array}{l}\text { Acquisition } \\
\& \text { Minority }\end{array}$ & $\begin{array}{c}\text { Greenfield \& } \\
\text { Minority }\end{array}$ & $\begin{array}{l}\text { Acquisition } \\
\& \text { Majority }\end{array}$ & $\begin{array}{l}\text { Acquisition } \\
\& \text { Minority }\end{array}$ \\
\hline \multicolumn{7}{|l|}{$\begin{array}{l}\text { Main explanatory } \\
\text { variables }\end{array}$} \\
\hline Family owned & $\begin{array}{l}-0.36 \\
(0.54)\end{array}$ & $\begin{array}{l}-1.12^{*} \\
(0.44)\end{array}$ & $\begin{array}{l}-3.06^{* *} \\
(1.10)\end{array}$ & $\begin{array}{l}-0.30 \\
(0.54)\end{array}$ & $\begin{array}{l}-0.93^{\dagger} \\
(0.48)\end{array}$ & $\begin{array}{l}-2.78^{* *} \\
(1.07)\end{array}$ \\
\hline Family managed & $\begin{array}{l}-0.52 \\
(0.53)\end{array}$ & $\begin{array}{l}-1.14^{* * *} \\
(0.36)\end{array}$ & $\begin{array}{l}-1.78^{* * *} \\
(0.57)\end{array}$ & $\begin{array}{l}-0.52 \\
(0.53)\end{array}$ & $\begin{array}{l}-1.16^{* *} \\
(0.36)\end{array}$ & $\begin{array}{l}-1.78^{* * *} \\
(0.57)\end{array}$ \\
\hline \multirow[t]{2}{*}{$\begin{array}{l}\text { Host country } \\
\text { experience }\end{array}$} & $0.20^{* *}$ & $0.17^{*}$ & $0.17^{* *}$ & 0.07 & $0.11^{*}$ & 0.08 \\
\hline & $(0.06)$ & & $(0.06)$ \\
\hline \multirow[t]{2}{*}{$\begin{array}{l}\text { Family owned } x \text { Host } \\
\text { country experience }\end{array}$} & & & & 0.20 & $0.42^{\dagger}$ & $0.63^{*}$ \\
\hline & & & & $(0.27)$ & $(0.25)$ & $(0.31)$ \\
\hline \multirow[t]{2}{*}{$\begin{array}{l}\text { Family managed } x \text { Host } \\
\text { country cluster } \\
\text { experience }\end{array}$} & & & & 0.17 & 0.01 & 0.12 \\
\hline & \multicolumn{6}{|c|}{ Deal-level controls } \\
\hline Horizontal expansion & $\begin{array}{l}1.10^{* *} \\
(0.34)\end{array}$ & $\begin{array}{l}1.38^{* * *} \\
(0.22)\end{array}$ & $\begin{array}{l}1.41^{* * *} \\
(0.43)\end{array}$ & $\begin{array}{l}1.13^{* * *} \\
(0.34)\end{array}$ & $\begin{array}{l}1.38^{* * *} \\
(0.22)\end{array}$ & $\begin{array}{l}1.44^{* * * *} \\
(0.44)\end{array}$ \\
\hline Vertical expansion & $\begin{array}{l}1.43^{\dagger} \\
(0.77)\end{array}$ & $\begin{array}{l}1.03^{* *} \\
(0.35)\end{array}$ & $\begin{array}{l}1.37 \\
(0.96)\end{array}$ & $\begin{array}{l}1.41^{\dagger} \\
(0.77)\end{array}$ & $\begin{array}{l}1.02^{* *} \\
(0.36)\end{array}$ & $\begin{array}{l}1.38 \\
(0.96)\end{array}$ \\
\hline Diversification & $\begin{array}{l}-0.14 \\
(1.33)\end{array}$ & $\begin{array}{l}2.07^{*} \\
(1.05)\end{array}$ & $\begin{array}{c}0.36 \\
(0.96)\end{array}$ & $\begin{array}{l}-0.18 \\
(1.34)\end{array}$ & $\begin{array}{l}2.04^{\dagger} \\
(1.06)\end{array}$ & $\begin{array}{c}0.29 \\
(0.91)\end{array}$ \\
\hline \multicolumn{7}{|l|}{ Parent-level controls } \\
\hline Parent size & $\begin{array}{l}-0.01 \\
(0.12)\end{array}$ & $\begin{array}{l}-0.16^{*} \\
(0.07)\end{array}$ & $\begin{array}{l}-0.26^{*} \\
(0.11)\end{array}$ & $\begin{array}{l}-0.01 \\
(0.12)\end{array}$ & $\begin{array}{l}-0.17^{* * *} \\
(0.07)\end{array}$ & $\begin{array}{l}-0.26^{*} \\
(0.11)\end{array}$ \\
\hline Parent age & $\begin{array}{c}0.00 \\
(0.01)\end{array}$ & $\begin{array}{c}0.00 \\
(0.01)\end{array}$ & $\begin{array}{c}0.00 \\
(0.01)\end{array}$ & $\begin{array}{c}0.00 \\
(0.09)\end{array}$ & $\begin{array}{c}0.00 \\
(0.01)\end{array}$ & $\begin{array}{c}0.00 \\
(0.01)\end{array}$ \\
\hline Parent diversification & $\begin{array}{l}-0.08 \\
(0.19)\end{array}$ & $\begin{array}{c}0.13 \\
(0.14)\end{array}$ & $\begin{array}{l}-0.12 \\
(0.37)\end{array}$ & $\begin{array}{l}-0.10 \\
(0.19)\end{array}$ & $\begin{array}{c}0.11 \\
(0.14)\end{array}$ & $\begin{array}{l}-0.16 \\
(0.40)\end{array}$ \\
\hline Labor intensity & $\begin{array}{c}0.72 \\
(0.61)\end{array}$ & $\begin{array}{c}0.12 \\
(0.39)\end{array}$ & $\begin{array}{l}1.02^{\dagger} \\
(0.55)\end{array}$ & $\begin{array}{c}0.73 \\
(0.59)\end{array}$ & $\begin{array}{c}0.14 \\
(0.40)\end{array}$ & $\begin{array}{c}1.02^{\dagger} \\
(0.58)\end{array}$ \\
\hline Listed & $\begin{array}{c}0.08 \\
(0.44)\end{array}$ & $\begin{array}{l}0.99^{* * * *} \\
(0.29)\end{array}$ & $\begin{array}{c}0.36 \\
(0.72)\end{array}$ & $\begin{array}{l}0.06 \\
(0.44)\end{array}$ & $\begin{array}{l}0.99^{* * * *} \\
(0.29)\end{array}$ & $\begin{array}{c}0.35 \\
(0.73)\end{array}$ \\
\hline Leverage & $\begin{array}{l}0.04^{* * *} \\
(0.01)\end{array}$ & $\begin{array}{l}-0.02 \\
(0.04)\end{array}$ & $\begin{array}{l}-0.20 \\
(0.18)\end{array}$ & $\begin{array}{l}0.04^{* * *} \\
(0.01)\end{array}$ & $\begin{array}{l}-0.01 \\
(0.04)\end{array}$ & $\begin{array}{l}-0.20 \\
(0.18)\end{array}$ \\
\hline Cash flow on assets & $\begin{array}{c}0.15 \\
(0.11)\end{array}$ & $\begin{array}{c}0.06 \\
(0.07)\end{array}$ & $\begin{array}{c}0.15 \\
(0.34)\end{array}$ & $\begin{array}{c}0.14 \\
(0.11)\end{array}$ & $\begin{array}{c}0.05 \\
(0.07)\end{array}$ & $\begin{array}{c}0.15 \\
(0.37)\end{array}$ \\
\hline \multicolumn{7}{|l|}{ Country-level controls } \\
\hline Psychic distance & $\begin{array}{c}0.43 \\
(0.27)\end{array}$ & $\begin{array}{l}-0.04 \\
(0.12)\end{array}$ & $\begin{array}{c}0.32 \\
(0.21)\end{array}$ & $\begin{array}{c}0.43 \\
(0.28)\end{array}$ & $\begin{array}{l}-0.03 \\
(0.12)\end{array}$ & $\begin{array}{c}0.33 \\
(0.21)\end{array}$ \\
\hline Geographic distance & $\begin{array}{l}-0.02 \\
(0.22)\end{array}$ & $\begin{array}{l}-0.16 \\
(0.13)\end{array}$ & $\begin{array}{l}-0.32 \\
(0.35)\end{array}$ & $\begin{array}{l}-0.02 \\
(0.22)\end{array}$ & $\begin{array}{l}-0.15 \\
(0.13)\end{array}$ & $\begin{array}{l}-0.31 \\
(0.35)\end{array}$ \\
\hline GDP growth & $\begin{array}{l}-3.56 \\
(7.52)\end{array}$ & $\begin{array}{l}-5.75 \\
(4.13)\end{array}$ & $\begin{array}{l}-11.11 \\
(6.99)\end{array}$ & $\begin{array}{l}-4.08 \\
(7.84)\end{array}$ & $\begin{array}{l}-6.12 \\
(4.19)\end{array}$ & $\begin{array}{c}-12.14^{\dagger} \\
(7.15)\end{array}$ \\
\hline GDP per capita & $\begin{array}{c}0.07 \\
(0.33)\end{array}$ & $\begin{array}{l}0.36^{\dagger} \\
(0.19)\end{array}$ & $\begin{array}{c}0.12 \\
(0.28)\end{array}$ & $\begin{array}{c}0.07 \\
(0.34)\end{array}$ & $\begin{array}{l}0.36^{\dagger} \\
(0.19)\end{array}$ & $\begin{array}{c}0.10 \\
(0.28)\end{array}$ \\
\hline Market capitalization & $\begin{array}{c}0.31 \\
(0.30)\end{array}$ & $\begin{array}{c}0.02 \\
(0.16)\end{array}$ & $\begin{array}{c}0.20 \\
(0.29)\end{array}$ & $\begin{array}{c}0.31 \\
(0.30)\end{array}$ & $\begin{array}{c}0.02 \\
(0.16)\end{array}$ & $\begin{array}{c}0.20 \\
(0.29)\end{array}$ \\
\hline \multirow[t]{2}{*}{$\begin{array}{l}\text { Time to start a new } \\
\text { business }\end{array}$} & -0.35 & 0.28 & $-1.93^{\dagger}$ & -0.36 & 0.20 & -2.09 \\
\hline & $(0.96)$ & $(0.47)$ & $(1.17)$ & $(0.97)$ & $(0.47)$ & $(1.30)$ \\
\hline Economic freedom & $\begin{array}{c}2.13 \\
(3.21)\end{array}$ & $\begin{array}{c}0.25 \\
(1.48)\end{array}$ & $\begin{array}{l}-1.49 \\
(2.32)\end{array}$ & $\begin{array}{c}2.22 \\
(3.23)\end{array}$ & $\begin{array}{c}0.03 \\
(1.50)\end{array}$ & $\begin{array}{l}-1.61 \\
(2.37)\end{array}$ \\
\hline Constant & $\begin{array}{l}-4.09 \\
(3.06)\end{array}$ & $\begin{array}{l}-1.41 \\
(1.97)\end{array}$ & $\begin{array}{l}-12.30^{* * *} \\
(3.920)\end{array}$ & $\begin{array}{l}-4.06 \\
(3.11)\end{array}$ & $\begin{array}{l}-1.18 \\
(1.97)\end{array}$ & $\begin{array}{c}-11.85^{* *} \\
(4.00)\end{array}$ \\
\hline Industry fixed effects & Yes & Yes & Yes & Yes & Yes & Yes \\
\hline Year fixed effects & Yes & Yes & Yes & Yes & Yes & Yes \\
\hline Observations & 1,045 & 1,045 & 1,045 & 1,045 & 1,045 & 1,045 \\
\hline
\end{tabular}


Figure 1. Average marginal effects on Greenfield probability of family-owned and family-managed firms at various levels of host country (base level is non-family firms).

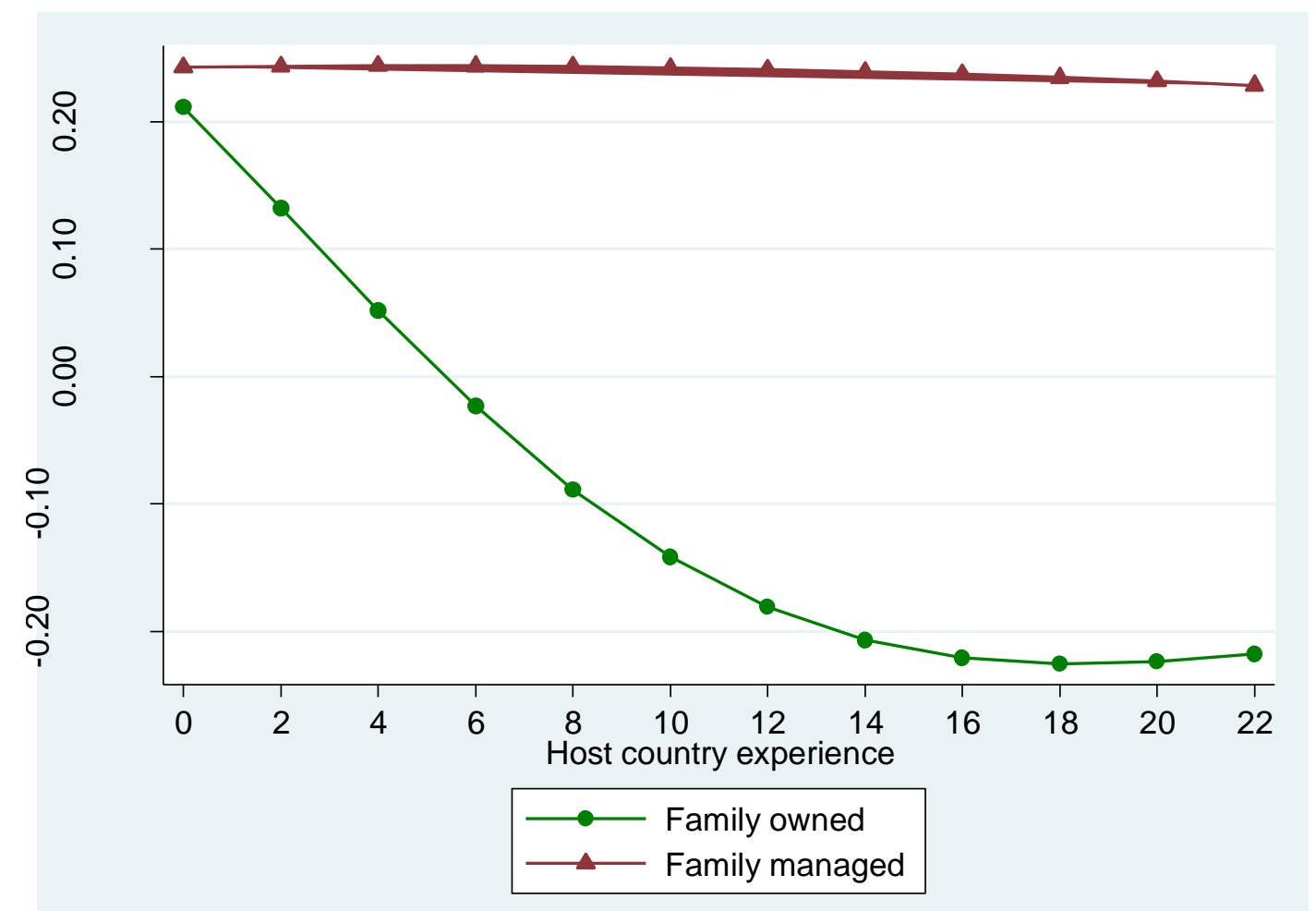




\begin{abstract}
APPENDICES
Appendix 1. Controls description

Deal-level controls

We collected and cross-checked information from different sources: Zephyr-Bureau van Dijk database (4-digit industry codes of parent companies and relevant subsidiaries), annual reports, and other companies' releases. Accordingly, we built the following four mutually exclusive categories (and the related dummies):

- Expansion in services, i.e., investments in forward and backward service activities, such as sales \& marketing, maintenance \& servicing, technical support, logistics \& transportation, and other services related to the core activity of the firm;

- Horizontal expansion, i.e., investments in the same manufacturing activities of the parent firm;

- Vertical expansion, i.e., investments in activities that are vertically (backward or forward) related to the parent firm's manufacturing activities; this category refers both to production in manufacturing, extraction, energy and construction and to functions strictly related to production, i.e., design, development \& testing, and research \& development;

- Diversification, i.e., investments in activities that are new to the parent firm.
\end{abstract}

\title{
Firm-level controls
}

Parent size. We measure the parent's size with the logarithm of the parent's number of employees. Parent age is measured by the difference between the year of the foreign entry and the parent's foundation year. Parent diversification is operationalized by counting the number of 4-digit industry codes in which the parent is active. Labor intensity is the ratio between the aggregate expenses for employees and the revenues of the firm; we log-transform it because of the log-normality of the distribution. Listed is a dummy variable taking the value 1 when the parent firm is listed and 0 otherwise. The variable Leverage is the ratio between the parent firm's debt and common equity. Cash flow on assets is the operating cash flow divided by the total assets to rescale it. All the firm-level data come from the AIDA-Bureau van Dijk database. 


\section{Country-level controls}

To measure the Psychic distance between Italy and the host countries, we adopt the Dow \& Karunaratna's (2006) indicator, which encompasses five dimensions (languages, religions, levels of industrial development, levels of education, and political systems):

$$
\text { Psychic distance }=\frac{1}{5} \sum_{k=1}^{5} \frac{\left(I_{i j k}\right)^{2}}{\operatorname{Var}(k)}
$$

where:

$I_{i j k}$ is the distance between country $i$ (i.e., Italy) and country $j$ (with $\mathrm{j}=1, \ldots, 63$ host countries) for the $k$-th dimension; and

$\operatorname{Var}(k)$ is the variance of the $k$-th dimension and aims to normalize for scale and heterogeneity across dimensions.

We collect Geographic distance between Italy and the foreign countries' capital cities from the CEPII database. Because of right-skewness of the distribution, the variable is log-transformed. GDP growth, GDP per capita and Market capitalization data come from the World Bank databases. Time to start a new business is the number of calendar days needed to complete all the required procedures to establish a firm. This number is then divided by 100 to rescale it. Data come from the World Bank's Doing Business database. Economic freedom is an index, developed by the Heritage Foundation and the Wall Street Journal, ranging from 0 to 100 (it has been divided by 100 in the analyses to rescale it). Higher values indicate economically freer countries. 
Appendix 2. Probit models (coefficients and average marginal effects). Dependent variable:

Establishment mode choice (greenfield $=1$ )

\begin{tabular}{|c|c|c|c|c|c|c|c|c|}
\hline & Coef. & $\begin{array}{c}\text { Marginal } \\
\text { effects }\end{array}$ & Coef. & $\begin{array}{c}\text { Marginal } \\
\text { effects }\end{array}$ & Coef. & $\begin{array}{c}\text { Marginal } \\
\text { effects }\end{array}$ & Coef. & $\begin{array}{c}\text { Marginal } \\
\text { effects }\end{array}$ \\
\hline \multicolumn{9}{|l|}{ Main explanatory variables } \\
\hline Family owned & & & $\begin{array}{c}0.86^{* * *} \\
(0.24)\end{array}$ & $\begin{array}{c}0.28^{* * *} \\
(0.07)\end{array}$ & $\begin{array}{l}0.74^{* *} \\
(0.24)\end{array}$ & $\begin{array}{l}0.24^{* *} \\
(0.07)\end{array}$ & $\begin{array}{l}0.64^{* *} \\
(0.24)\end{array}$ & $\begin{array}{l}0.24^{* *} \\
(0.07)\end{array}$ \\
\hline \multirow[t]{2}{*}{ Family managed } & & & $0.85^{* * *}$ & $0.28^{* * *}$ & $0.72^{* * * *}$ & $0.23^{* * *}$ & $0.74^{* * * *}$ & $0.24^{* * * *}$ \\
\hline & & & $(0.19)$ & $(0.06)$ & $(0.19)$ & $(0.06)$ & $(0.19)$ & $(0.07)$ \\
\hline Host country experience & & & & & $\begin{array}{l}-0.08^{*} \\
(0.04)\end{array}$ & $\begin{array}{l}-0.02^{*} \\
(0.01)\end{array}$ & $\begin{array}{l}-0.05^{*} \\
(0.02)\end{array}$ & $\begin{array}{c}-0.03^{* *} \\
(0.01)\end{array}$ \\
\hline \multicolumn{9}{|l|}{ Interaction effects } \\
\hline \multirow[t]{2}{*}{$\begin{array}{l}\text { Family owned } x \text { Host country } \\
\text { experience }\end{array}$} & & & & & & & $-0.25^{*}$ & \\
\hline & & & & & & & $(0.12)$ & \\
\hline \multirow{2}{*}{$\begin{array}{l}\text { Family managed } x \text { Host country } \\
\text { experience }\end{array}$} & & & & & & & 0.00 & \\
\hline & & & & & & & $(0.05)$ & \\
\hline \multicolumn{9}{|l|}{ Deal-level controls } \\
\hline Horizontal expansion & $\begin{array}{c}-0.84^{* * *} \\
(0.11)\end{array}$ & $\begin{array}{c}-0.26^{* * *} \\
(0.03)\end{array}$ & $\begin{array}{c}-0.72^{* * *} \\
(0.11)\end{array}$ & $\begin{array}{c}-0.22^{* * *} \\
(0.03)\end{array}$ & $\begin{array}{c}-0.73^{* * *} \\
(0.12)\end{array}$ & $\begin{array}{c}-0.22^{* * *} \\
(0.03)\end{array}$ & $\begin{array}{c}-0.73^{* * *} \\
(0.12)\end{array}$ & $\begin{array}{c}-0.22^{* * *} \\
(0.03)\end{array}$ \\
\hline \multirow[t]{2}{*}{ Vertical expansion } & $-0.61^{*}$ & $-0.19^{* *}$ & $-0.47^{*}$ & $-0.14^{*}$ & $-0.53^{*}$ & $-0.16^{*}$ & $-0.53^{*}$ & $-0.16^{*}$ \\
\hline & $(0.24)$ & $(0.07)$ & $(0.21)$ & $(0.06)$ & $(0.22)$ & $(0.07)$ & $(0.22)$ & $(0.06)$ \\
\hline \multirow[t]{2}{*}{ Diversification } & $-1.16^{*}$ & $-0.36^{*}$ & $-1.09^{\dagger}$ & $-0.33^{*}$ & $-1.06^{*}$ & $-0.32^{*}$ & $-1.05^{*}$ & $-0.31^{*}$ \\
\hline & $(0.55)$ & $(0.17)$ & $(0.56)$ & $(0.17)$ & $(0.51)$ & $(0.15)$ & $(0.52)$ & $(0.15)$ \\
\hline \multicolumn{9}{|l|}{ Parent-level controls } \\
\hline \multirow[t]{2}{*}{ Parent size } & $0.09^{*}$ & $0.03^{*}$ & $0.09^{*}$ & $0.03^{*}$ & $0.10^{* *}$ & $0.03^{* *}$ & $0.10^{* *}$ & $0.03^{* *}$ \\
\hline & $(0.04)$ & $(0.01)$ & $(0.04)$ & $(0.01)$ & $(0.04)$ & $(0.01)$ & $(0.04)$ & $(0.01)$ \\
\hline \multirow[t]{2}{*}{ Parent age } & -0.00 & -0.00 & -0.00 & -0.00 & -0.00 & -0.00 & -0.00 & -0.00 \\
\hline & $(0.00)$ & $(0.00)$ & $(0.00)$ & $(0.00)$ & $(0.00)$ & $(0.00)$ & $(0.00)$ & $(0.00)$ \\
\hline \multirow[t]{2}{*}{ Parent diversification } & -0.07 & -0.02 & -0.08 & -0.02 & -0.07 & -0.02 & -0.05 & -0.01 \\
\hline & $(0.09)$ & $(0.03)$ & $(0.08)$ & $(0.03)$ & $(0.08)$ & $(0.02)$ & $(0.08)$ & $(0.02)$ \\
\hline \multirow[t]{2}{*}{ Labor intensity } & 0.06 & 0.02 & 0.01 & 0.00 & -0.01 & -0.00 & -0.04 & -0.01 \\
\hline & $(0.20)$ & $(0.06)$ & $(0.20)$ & $(0.06)$ & $(0.20)$ & $(0.06)$ & $(0.20)$ & $(0.06)$ \\
\hline Listed & $-0.48^{* *}$ & $-0.15^{* *}$ & $-0.59^{* * *}$ & $-0.18^{* * *}$ & $-0.55^{* *}$ & $-0.17^{* * *}$ & $-0.54^{* *}$ & $-0.16^{* *}$ \\
\hline & $(0.17)$ & $(0.05)$ & $(0.17)$ & $(0.05)$ & $(0.17)$ & $(0.05)$ & $(0.17)$ & $(0.05)$ \\
\hline Leverage & 0.02 & 0.01 & 0.02 & 0.01 & 0.02 & 0.01 & 0.02 & 0.00 \\
\hline & $(0.02)$ & $(0.01)$ & $(0.02)$ & $(0.01)$ & $(0.02)$ & $(0.01)$ & $(0.02)$ & $(0.01)$ \\
\hline Cash flow on assets & -0.04 & -0.01 & -0.02 & -0.01 & -0.02 & -0.01 & -0.01 & -0.00 \\
\hline & $(0.04)$ & $(0.01)$ & $(0.04)$ & $(0.01)$ & $(0.04)$ & $(0.01)$ & $(0.04)$ & $(0.01)$ \\
\hline Country-level controls & & & & & & & & \\
\hline Psychic distance & 0.00 & 0.00 & 0.01 & 0.00 & 0.02 & 0.01 & 0.02 & 0.00 \\
\hline & $(0.07)$ & $(0.02)$ & $(0.06)$ & $(0.02)$ & $(0.06)$ & $(0.02)$ & $(0.06)$ & $(0.02)$ \\
\hline Geographic distance & 0.09 & 0.03 & 0.10 & 0.03 & 0.10 & 0.03 & 0.10 & 0.03 \\
\hline & $(0.07)$ & $(0.02)$ & $(0.07)$ & $(0.02)$ & $(0.07)$ & $(0.02)$ & $(0.07)$ & $(0.02)$ \\
\hline GDP growth & $3.08^{\dagger}$ & $0.96^{\dagger}$ & $3.40^{\dagger}$ & $1.04^{\dagger}$ & 2.74 & 0.83 & $3.19^{\dagger}$ & $0.95^{\dagger}$ \\
\hline & (1.76) & $(0.55)$ & (1.79) & $(0.54)$ & (1.79) & $(0.54)$ & (1.78) & $(0.53)$ \\
\hline GDP per capita & $-0.25^{*}$ & $-0.08^{* * *}$ & $-0.23^{*}$ & $-0.07^{*}$ & $-0.21^{*}$ & $-0.06^{*}$ & $-0.21^{*}$ & $-0.06^{*}$ \\
\hline & $(0.10)$ & $(0.03)$ & $(0.10)$ & $(0.03)$ & $(0.10)$ & $(0.03)$ & $(0.10)$ & $(0.03)$ \\
\hline Market capitalization & -0.00 & -0.00 & -0.01 & -0.00 & 0.01 & 0.00 & 0.02 & 0.00 \\
\hline & $(0.08)$ & $(0.03)$ & $(0.09)$ & $(0.03)$ & $(0.08)$ & $(0.03)$ & $(0.09)$ & $(0.03)$ \\
\hline Time to start a new business & -0.08 & -0.02 & -0.06 & -0.02 & -0.08 & -0.02 & -0.01 & -0.00 \\
\hline & $(0.25)$ & $(0.08)$ & $(0.25)$ & $(0.08)$ & $(0.25)$ & $(0.08)$ & $(0.25)$ & $(0.08)$ \\
\hline Economic freedom & 0.25 & 0.08 & 0.36 & 0.11 & 0.06 & 0.02 & 0.17 & 0.05 \\
\hline & $(0.79)$ & $(0.25)$ & $(0.80)$ & $(0.25)$ & $(0.80)$ & $(0.24)$ & $(0.82)$ & $(0.25)$ \\
\hline Constant & $1.85^{\dagger}$ & & 0.74 & & 0.52 & & 0.34 & \\
\hline & $(1.05)$ & & $(1.07)$ & & $(1.03)$ & & $(1.03)$ & \\
\hline Industry fixed effects & Yes & Yes & Yes & Yes & Yes & Yes & Yes & Yes \\
\hline Year fixed effects & No & No & No & No & No & No & No & No \\
\hline Observations & 1,045 & 1,045 & 1,045 & 1,045 & 1,045 & 1,045 & 1,045 & 1,045 \\
\hline $\mathrm{FO}=\mathrm{FM}(\mathrm{p}$-value $)$ & & & 0.95 & & 0.90 & & 0.61 & \\
\hline Efron's pseudo $\mathrm{R}^{2}$ & $22.5 \%$ & & $24.5 \%$ & & $25.4 \%$ & & $26.0 \%$ & \\
\hline Ratio of correct classifications & $71.96 \%$ & & $73.59 \%$ & & $73.21 \%$ & & $73.40 \%$ & \\
\hline Wald test ${ }^{\text {a }}$ & & & $20.16^{* * *}$ & & $26.71^{\text {**** }}$ & & $39.83^{* * *}$ & \\
\hline (degrees of freedom) & & & (2) & & (3) & & (5) & \\
\hline
\end{tabular}

Note:

Coefficients report firm-level clustered standard errors in parentheses

Marginal effects report robust standard errors in parentheses

${ }^{\dagger} p<0.10,{ }^{*} p<0.05,{ }^{* *} p<0.01,{ }^{* * *} p<0.001$

a Reference model is (1) 